\title{
Sourcing tactics to achieve cost savings: developing a formative method of measurement
}

\section{Frank Henrik Hesping* and Holger Schiele}

\author{
University of Twente, \\ P.O. Box 217, NL 7500 AE, \\ Enschede, The Netherlands \\ Email: f.hesping@utwente.nl \\ Email: h.schiele@utwente.nl \\ *Corresponding author
}

\begin{abstract}
Sourcing levers describe tactics to achieve sourcing targets for diverse categories of materials or services. However, relevant research has been prevented inasmuch as the sourcing lever concept lacks explicit conceptualisation and a method of measurement. To fill this gap, this study developed a formative method of measurement for sourcing tactics. In the index development process, a literature review built the basis for highly interactive world café discussions with business professionals. Resulting measures have been tested in 107 sourcing projects within one large European automotive OEM. The measurement models build the basis for future empirical investigations about conditions, contingencies and antecedents for successful sourcing tactics application. In practice, the formative indicators can serve as a checklist to identify cost saving potentials and pave the way for systematic cost saving approaches with strategic sourcing.
\end{abstract}

Keywords: scale development; literature review; world café; sourcing levers; sourcing tactics; purchasing strategy.

Reference to this paper should be made as follows: Hesping, F.H. and Schiele, H. (2016) 'Sourcing tactics to achieve cost savings: developing a formative method of measurement', Int. J. Procurement Management, Vol. 9, No. 4, pp.473-504.

Biographical notes: Frank Henrik Hesping is a Research Associate at the University of Twente, in Enschede, The Netherlands. At the Chair of Technology Management - Innovation of Operations, he focused his research on strategic purchasing planning. In 2011, he was awarded a University Diploma in Industrial Engineering and Management from the Karlsruhe Institute of Technology (KIT), the former University of Karlsruhe, Germany. In 2010, he graduated from the Australian School of Business and holds a Master in Technology Management from the University of New South Wales (UNSW), Australia.

Holger Schiele obtained both his $\mathrm{PhD}$ and his Habilitation (venia legendi) in Business Administration from Leibniz Universität Hannover, Germany. He holds the Chair for Technology Management - Innovation of Operations at the University of Twente, The Netherlands. His research interests include innovations from and with suppliers, preferred customership, innovative clusters and modes of academic-practitioner collaboration. Besides academia, he has worked for ten years at the strategy department of Preussag AG, as consultant for PricewaterhouseCoopers and as project manager with $\mathrm{H} \& \mathrm{Z}$ Business Consulting. He is the author of management books (\#1 Financial Times Deutschland list) and numerous scientific papers. 
This paper is a revised and expanded version of a paper entitled 'Tactics at the category level of purchasing: a formative method of measurement' presented at IPSERA, Amsterdam, 29 March to 1 April 2015.

\section{Introduction: sourcing levers require a method for measurement}

In the past, tactics for purchasing strategy implementation were typically considered for the whole purchasing function encompassing the entire range of materials and buyer-supplier relationships (Hesping and Schiele, 2015; Karjalainen and Salmi, 2013). Recently however, it became generally accepted that "not all materials and buyer-supplier relationships are to be managed the same way" [Karjalainen and Salmi, (2013), p.114]. Rather, "companies frequently buy differently by [product] category" [Caniato et al., (2014), p.6] as "strategic sourcing decisions [...] are always decided specifically for each category and their supply market conditions" [Essig, (2011), p.143]. Today, scholars argue that firms may differentiate hundreds of so called 'sourcing categories'. Each sourcing category, e.g., 'metal sheets', 'leather', 'cables' etc., groups similar materials or services purchased from an overlapping group of suppliers (Cousins et al., 2008; Horn et al., 2013; Monczka et al., 2008).

To achieve cost savings, innovation and other performance goals, each sourcing category requires a tailored set of tactics which have been named 'sourcing levers' (Hesping and Schiele, 2015; Horn et al., 2013; Luzzini et al., 2012; Schiele et al., 2011; Schuh et al., 2011; Schumacher et al., 2008). Sourcing levers have an immediate practical relevance as they directly address actions that decision makers can take to achieve performance targets (Cuervo-Cazurra et al., 2013). If the sourcing category, 'leather' for example relies on a single source, the 'extension of supply base' lever might be used to increase competitive intensity to cut prices.

However, most publications "only considered the first steps of portfolio management, i.e., category classification and strategic priorities. Other studies might consider which levers and tools are used according to the different types of categories and different category priorities" [Luzzini et al., (2012), p.1036].

In the past, research on purchasing strategies and tactics focused on the overall company or individual products. Rather little has been done to better understand sourcing tactics at the category level of purchasing (Ateş, 2014; Hesping and Schiele, 2015; Karjalainen and Salmi, 2013). Relevant research has been prevented inasmuch as the concept of sourcing levers appears to be only loosely defined in contemporary literature. "The sourcing lever concept $[\ldots]$ has not received significant discussion in the academic literature. Further empirical investigation of what tactics and underlying activities category managers employ would be interesting" [Hesping and Schiele, (2015), p.148]. To enable future empirical investigations, sourcing levers require more explicit conceptualisation as well as a method of measurement (Hesping and Schiele, 2015; Luzzini et al., 2012).

The present paper seeks to fill this gap by delineating the conceptual content taken by the sourcing lever concept and to develop measures that are capable to capture this. The objective of this paper is to define and provide a method of measurement for the sourcing lever concept as a step towards theory building, enabling future research (Wacker, 1998). 
World café methodology and survey research were used to empirically validate the developed measures in 107 sourcing projects within one large European automotive OEM. The study makes three important contributions:

1 first, it delineates the conceptual content of the sourcing lever constructs, fostering its theoretical foundation

2 second, it makes sourcing lever constructs measurable and thus applicable to a wide range of research questions

3 third, it has immediate relevance for practice as it reveals the actions that purchasers may take to improve purchasing performance.

This paper is a fundamental step towards understanding sourcing levers; the antecedents of purchasing performance at the category level of purchasing. The study provides scholars and practitioners with measures for effective planning of tactical sourcing levers.

The paper is organised as follows:

1 initially, contemporary literature about sourcing levers has been reviewed

2 next, measurement models for sourcing levers have been developed and tested

3 the paper concludes by highlighting implications, discussing limitations and presenting future research opportunities.

\section{Conceptual framework: sourcing tactics to reach performance targets}

Most purchasers are confronted with the question about how to achieve yearly cost saving targets. To address this, sourcing levers provide a checklist of possible cost saving approaches.

As a distinguishing feature, sourcing levers focus on a group of purchases. These so called 'sourcing categories' "include materials or services of a similar type provided by the same group of suppliers" [Schiele et al., (2011), p.322] forming a distinct supply market (Boutellier and Zagler, 2000; Drake et al., 2013). Examples of sourcing categories may be 'metal sheets', 'leather', 'cables', 'lighting', 'battery systems' and so on. A sourcing category does likely neither include only one single material or supplier nor the entire spend managed by the purchasing function. In most cases, a sourcing category includes multiple parts and multiple suppliers (Horn et al., 2013; Li et al., 2014). In a category management approach, firms use dedicated purchasing agents; so called 'category managers' that responsibly manage all sourcing activities within one sourcing category (Ateş, 2014; Driedonks, 2010; Sundtoft and Sigurbjornsson, 2013). The category management concept developed in a retail context, where similar consumer goods were grouped for joint marketing, product offerings and to optimise the overall product portfolio, cross-sales and shelf management (Leeflang and Parreño-Selva, 2012; Lindblom et al., 2009). In purchasing, category management mainly builds on portfolio theory, used to place purchasing goods into a limited number of four or nine portfolio cells (Gelderman and Semeijn, 2006; Nellore and Söderquist, 2000). However, to account better for the peculiarities of each material or service group, organisations moved towards a finer differentiation of sourcing categories. In a modern category management approach, a firm may distinguish several hundreds of sourcing categories based on 
differentiators such as production technology, supplier competences or market-facing areas (Ateş, 2014; Monczka and Markham, 2007; Van Weele, 2010).

A recent research stream addresses the issue of planning the actions to realise performance goals for a sourcing category. Several authors present sets of sourcing tactics that became known as 'sourcing levers' (Hesping and Schiele, 2015; O'Brien, 2012; Schiele et al., 2011; Schuh et al., 2011; Schumacher et al., 2008; Stollenwerk, 2012). The concept of sourcing levers is not new to literature in the way that it describes tactics used to operationalise general strategy. From strategic management literature one learns that general strategy can be operationalised through a diverse set of tactics (Hillman and Hitt, 1999). Different from general strategy, tactics form clusters of activities with a concrete time specification and traceable milestones (Mintzberg, 1994).

When transitioning from general strategic goals for a sourcing category to specific actions, category managers may discuss various tactical sourcing levers. Each sourcing lever consists of "a set of similar measures that are used to improve the firm's sourcing performance in a commodity group [or sourcing category]" [Schiele, (2007), p.279]. In contrast to strategic goals, sourcing levers do not provide a general orientation for purchasing activities, such as achieving annual cost saving targets (Schiele et al., 2011). Sourcing levers describe a typology of activities through which the goals shall be realised (Hess, 2010) (see Figure 1).

Figure 1 Conceptual framework - sourcing levers describe tactics to reach performance goals

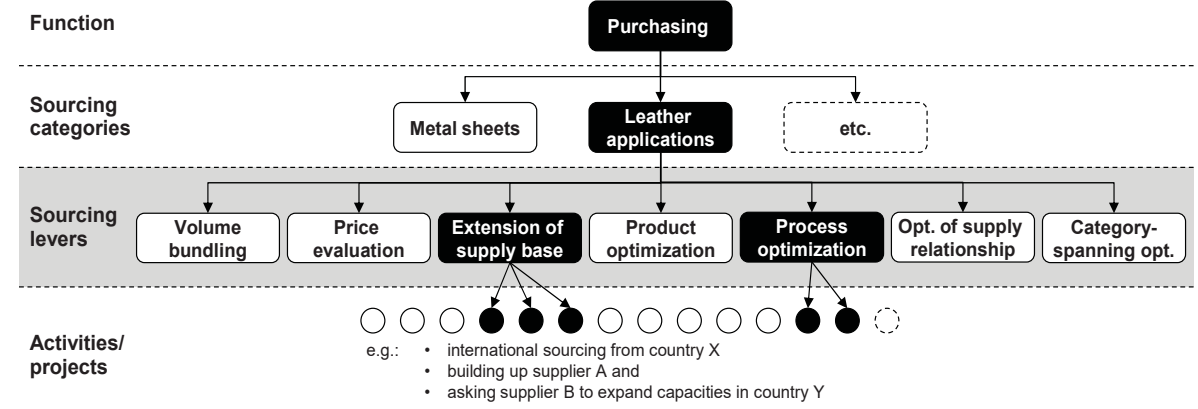

Scholars have developed multiple sourcing lever frameworks. Schuh and Bremicker (2005) speak of the 'sourcing lever diamond', Schumacher et al. (2008) use 'seven levers', Schuh et al. (2008) group levers in a 'purchasing chessboard', Hess (2010) uses the lever term in combination with different 'fields of actions', while Büsch (2011) focuses on 'three key levers', O'Brien (2012) again presents 'five value levers', while Cox (2014) discusses 'seven groups of tactical sourcing levers'.

In the subsequent sections of this study, the so far most empirically elaborated framework by Schiele et al. (2011) served as a conceptual structure in the measurement development process. Schiele et al. (2011) report a successful application of seven core sourcing levers in 134 cross-functional cost-saving workshops:

1 'volume bundling', to leverage larger purchasing volumes

2 'price evaluation' as a new form of negotiating prices based on cost information

3 'extension of supplier base' to introduce new supply sources 
4 'product optimisation' to modify the material or service

5 'process optimisation' to simplify the buyer-seller interface

6 'optimisation of supply relationship' to partner with suppliers

7 'category-spanning optimisation' to consider possible synergies across sourcing categories (see Figure 1).

Literature emphasises the immediate practical relevance of the sourcing lever concept as a tool "used to achieve the strategic goal of cost reduction" [Schiele et al., (2011), p.322]. Still, the conceptualisation of sourcing levers in contemporary literature is relatively limited (Hesping and Schiele, 2015). It remains largely unclear, which conceptual content is captured by each sourcing lever. Hence, it was not surprising that the literature review did not identify existing sourcing lever scales that would serve as measures in future empirical studies.

\section{Methodology: index development with formative indicators}

To address the paucity of conceptualisation in literature, this study set out to develop indicators and measurement models that can serve practitioners and academics as a tool to address the sourcing lever concept in future research.

'Indicators', also known as measures or items, “are observable, quantifiable scores obtained through self-report, interview, observation, or other empirical means. They are used to examine 'constructs', which are abstractions that describe a phenomenon of theoretical interest or other empirical means" [Petter et al., (2007), p.625]. Indicators can be used in a reflective or a formative 'measurement model' to capture the conceptual content of an unobservable construct (Jarvis et al., 2003). From a theoretical point of view, the main difference between reflective and formative models is the direction of causality (Cenfetelli and Bassellier, 2009). In a reflective model, the construct exists independently of the indicators used. All reflective indicators of a construct share a common theme and are assumed to be equally valid (Cenfetelli and Bassellier, 2009; MacKenzie et al., 2011). But, a formative construct is a combination or index of its indicators. Formative indicators do not need to share a common theme (Coltman et al., 2008; Diamantopoulos et al., 2008).

For this study, formative measurement models have been chosen due to theoretical and practical considerations. On a theoretical level, sourcing levers consist per definition of a set of distinct, directly addressable activities (O'Brien, 2012; Schiele, 2007; Schiele et al., 2011; Schuh and Bremicker, 2005) and the formative model "provides an option for researchers to use measures that tend to be specific, actionable attributes of a phenomenon" [Cenfetelli and Bassellier, (2009), p.690]. On a practical level, formative measurement of sourcing levers makes a strong diagnostic tool, since decision makers are able to track the contribution of each indicator (i.e., a specific sourcing activity such as sourcing from a supplier in a low cost country) to the corresponding index for the sourcing lever construct (Cenfetelli and Bassellier, 2009). In the essence, the indicators in formative sourcing lever models represent a checklist of specific, actionable cost saving activities which can be interpreted in isolation and directly implemented by 'front-line' purchasing agents. 
To develop the formative measurement models, the study follows the index development procedure proposed by Diamantopoulos and Winklhofer (2001):

1 'content specification' to delineate each sourcing lever's conceptual content

2 'indicator specification' to refine relevant indicators for each sourcing lever

3 'empirical evaluation' to test the measurement models in a large-scale survey (see Figure 2).

Figure 2 Methodology - index development with formative indicators

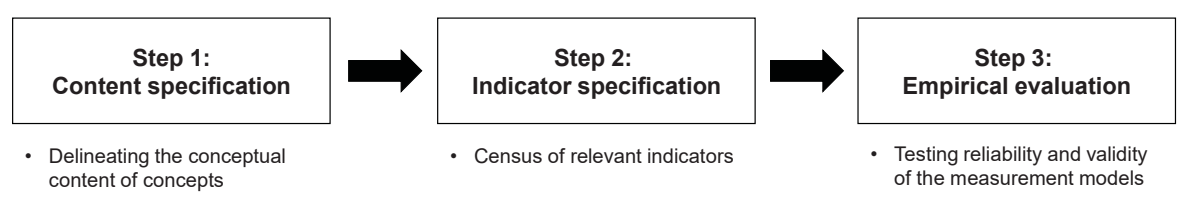

\subsection{Content specification: delineating the conceptual content of the concepts}

In the first step of index development, a literature review has been used to define the conceptual content (i.e., the phenomenon of theoretical interest) for each of the seven core sourcing levers (Churchill, 1979; Diamantopoulos and Winklhofer, 2001) (see Table 1). Based on these definitions, cost saving approaches have been grouped that might serve as indicators in the formative measurement models (see the Appendix - Table A1). Literature search focused on journals in the disciplines of operations and supply (chain) management, general management, marketing management and international business.

Table 1 Content specification - sourcing levers and their conceptual content

\begin{tabular}{|c|c|}
\hline Sourcing lever & Conceptual content \\
\hline & The category managers' engagement in... \\
\hline Volume bundling & $\begin{array}{l}\text {... consolidating demand and increasing purchasing volume per request } \\
\text { for quotation. }\end{array}$ \\
\hline Price evaluation & $\begin{array}{l}\text {... forming price targets and analysing suppliers' bids and cost } \\
\text { structures. }\end{array}$ \\
\hline $\begin{array}{l}\text { Extension of supply } \\
\text { base }\end{array}$ & $\begin{array}{l}\text {... increasing the number of sources and bidders per request for } \\
\text { quotation. }\end{array}$ \\
\hline Product optimisation & $\begin{array}{l}\text {... making modifications to the design, functions and materials of the } \\
\text { purchased items. }\end{array}$ \\
\hline Process optimisation & ... optimising processes related to the buyer-supplier interfaces. \\
\hline $\begin{array}{l}\text { Optimisation of } \\
\text { supply relationship }\end{array}$ & $\begin{array}{l}\text {... establishing and maintaining effective relationships between buyer } \\
\text { and suppliers in the market. }\end{array}$ \\
\hline $\begin{array}{l}\text { Category-spanning } \\
\text { optimisation }\end{array}$ & $\begin{array}{l}\text {.. optimising the interfaces to and balancing trade-offs with other } \\
\text { sourcing categories to enforce and coordinate mutual approaches. }\end{array}$ \\
\hline
\end{tabular}




\subsubsection{Volume bundling: consolidating demand and increasing purchasing volume per request for quotation}

Bundling is "the aggregation of two or more items (product and/or services) by the buyer into a bundle that is put up for a bid to potential suppliers as a single RFQ [request for quotation]" [Schoenherr and Mabert, (2008), p.81]. A main argument for bundling are volume effects and associated price discounts due to scale effects (Kaicker et al., 1995; Prince et al., 2013). Beyond volume, items can be bundled to tie unattractive items (e.g., with small volume) to attractive items to create offer dependence (Schoenherr and Mabert, 2008). To tap bundling potential, volumes can be concentrated on a few sources (Smart and Dudas, 2007), demand can be consolidated across product groups and business units (Karjalainen, 2011; Nollet and Beaulieu, 2005) and new volume can be tied to existing volume (Schoenherr and Mabert, 2008; Stremersch and Tellis, 2002).

- The conceptual content of the 'volume bundling' lever is limited to the category managers' engagement in consolidating demand and increasing purchasing volume per request for quotation.

\subsubsection{Price evaluations: forming price targets and analysing suppliers' bids and cost structures}

Due to its intensive supplier contact, purchasing is particularly related to supplier cost management and price analysis (Kulmala, 2004; Romano and Formentini, 2012). Transparency about suppliers' costs and prices does not only help to evaluate the products' total cost impact beyond purchase price but also builds the basis for identifying technical cost drivers and discussing possible price reduction opportunities with the suppliers. Price evaluation techniques include price analysis and cost structure analysis (Ellram, 1996). Price analysis techniques focus on comparison of quoted prices with past offers or similar purchases (Daly and Nath, 2005; Ellram, 1996). Cost structure analysis can be used to compare own calculations with offered prices (Ellram, 1996) and includes cost breakdowns (Romano and Formentini, 2012), cost regression (Newman and Krehbiel, 2007) and value analysis (Hartley, 2000; Yoshikawa et al., 1994).

- The conceptual content of the 'price evaluation' lever is limited to the category managers' engagement in forming price targets and analysing suppliers' bids and cost structures.

\subsubsection{Extension of supply base: increasing the number of sources and bidders per request for quotation}

The supply base design, and thus the number of suppliers, determines competition in the supply market (Li, 2013). Introducing new suppliers into the supply base, even if not awarded with a contract, may lead to better offers by the established bidders (Gnyawali and Madhavan, 2001). Extension of the supply base may be done through international sourcing and developing local or foreign sources. International purchasing offices may be used in a global scouting to identify overseas suppliers (Jia et al., 2014a; Sartor et al., 2014), competences of potential suppliers may be developed directly (Sillanpää et al., 2015; Sucky and Durst, 2013) or indirectly by gradually awarding business to build their 
capability and experience for future successful bids (Handfield et al., 2000; Krause et al., 1998).

- The conceptual content of the 'extension of supply base' lever is limited to the category managers' engagement in increasing the number of sources and bidders per request for quotation.

\subsubsection{Product optimisation: making modifications to the design, functions and materials of the purchased items}

The product design determines development and production costs as well as bargaining power and dependence in supply markets. High technological complexity often hinders participation of a number of suppliers, e.g., from a low-cost country, in competitive bidding (Khan et al., 2008; Luo et al., 2011; Smith, 1999). Furthermore, common, reused parts enable to increase volumes per part and thus bargaining power (Luo et al., 2011). Moreover, product design and degree of customisation have effects on logistics (Pradhan and Routroy, 2014; Ratha, 2014), as well as the ability to switch suppliers (Patala et al., 2014) or to respond to changing volume requirements and bottlenecks (Khan et al., 2008). Product optimisation includes internal engagement of purchasing into cross-functional product development teams (Danese and Filippini, 2010; Hong and Hartley, 2011; Lakemond et al., 2001; Melander and Lakemond, 2014) and bringing suppliers' external expertise into the product development process (Handfield et al., 1999; McGinnis and Vallopra, 1999; Wagner, 2012). Furthermore, purchasing may stimulate supplier competition to break technological lock-in situations and ultimately pressure suppliers to engage in product improvements (Song and Di Benedetto, 2008; Wynstra et al., 2003).

- The conceptual content of the 'product optimisation' lever is limited to the category managers' engagement in making modifications to the design, functions and materials of the purchased items.

\subsubsection{Process optimisation: optimising processes related to the buyer-supplier interfaces}

Process optimisation addresses the efficiency and effectiveness of the buyer-supplier interface to reduce transaction costs between companies. These improvements mainly focus on information exchange, transparency (Yang et al., 2009) and fast process cycle (Emiliani, 2000). Process improvements include electronic data exchange, collaboration and joint business process engineering (Labro, 2006). Electronic data exchange can be used to enhance information processing through the internet (Emiliani, 2000; Mukhopadhyay and Kekre, 2002; Tai et al., 2010). Collaboration encourages supply chain partners to jointly engage in planning, forecasting, replenishment, resource sharing as well as collaborative process operation and improvement (Nakano, 2009; Ramanathan and Gunasekaran, 2014). This includes several practices such as vendor managed inventory, continuous replenishment, quality and capacity management (Cao and Zhang, 2011; Ramanathan and Gunasekaran, 2014).

- The conceptual content of the 'process optimisation' lever is limited to the category managers' engagement in optimising processes related to the buyer-supplier interfaces. 


\subsubsection{Optimisation of supply relationship: establishing and maintaining effective relationships between buyer and suppliers in the market}

Optimisation of supply relationship focuses on a long-term perspective and joint efforts with suppliers (Hüttinger et al., 2012; Loppacher et al., 2011; Lui and Ngo, 2012; Nyaga et al., 2010). Relationship efforts may include supplier qualification, supplier incentives and relationship marketing. Supplier qualification includes investments into training suppliers, quality advice and site visits (Blonska et al., 2013; Krause and Scannell, 2002; Li et al., 2012a). Supplier incentives require less direct involvement and can be used to encourage suppliers' improvements through goal setting, supplier evaluation, rewards and certification (Blonska et al., 2013; Krause et al., 2007). To gain preferential treatment, a buyer may strive to become a preferred customer of the supplier. Relationship marketing tools may include extensive field contact, timely payments and fairly behaviour (Hüttinger et al., 2012; Schiele et al., 2012).

- The conceptual content of the 'optimisation of supply relationship' lever is limited to the category managers' engagement in establishing and maintaining effective relationships between buyer and suppliers in the market.

\subsubsection{Category-spanning optimisation: optimising the interfaces to and balancing trade-offs between sourcing categories}

Sourcing categories may be interrelated. Cheaper paper might increase ink usage and thus the overall costs per page (Schumacher et al., 2008). Changes to the car frame may cause changes to cable design and corresponding attachment clips. Some categories share the same or similar components or one product platform and thus buy from the same group of suppliers (Agrawal et al., 2013; Liu et al., 2010; Thomas et al., 2014). Therefore, as Kamakura and Kang (2007) state, category managers should think globally (across categories) and act locally (for their category). Coordinating a supplier's volume across categories for example can be used to determine a desired overall dependence on supply chain partners and a joint supplier strategy (Castaldo et al., 2009). To realise synergy potentials and enforce mutual approaches, decentralised category teams may coordinate their activities in a category-spanning, category management approach (Driedonks, 2010; Englyst et al., 2008; Schotanus and Telgen, 2007).

- The conceptual content of the 'category-spanning optimisation' lever is limited to the category managers' engagement in optimising the interfaces to and balancing trade-offs with other sourcing categories to enforce and coordinate mutual approaches.

\subsection{Indicator specification: a census of relevant indicators}

The second step of index development builds on the sourcing lever definitions from the previous sections. Potential indicators for each sourcing lever were recorded during the literature review (see the Appendix - Table A1). This initial list of indicators was further developed through intense collaboration with practitioners, with the aim to use the refined indicators as items in the ultimate survey stage. 
The initial list of potential indicators included a collection of cost saving approaches identified in literature. However, the indicators in this list showed large conceptual overlaps (see the Appendix - Table A1). For example, literature addressing the 'extension of supply base' lever uses terms such as 'global sourcing' (Kotabe and Murray, 2004), 'international outsourcing' (Mol et al., 2005) and 'offshore sourcing' (Nassimbeni, 2006) to describe very similar aspects of purchasing from a supplier in a foreign country.

However, formative measurement models require high conceptual disparity between the indicators (Cenfetelli and Bassellier, 2009; Diamantopoulos et al., 2008). Furthermore, different from reflective indicators, formative indicators cannot be a selection of indicators relating to the construct. In formative measurement models, all relevant indicators must be included to capture all major facets of the construct (Diamantopoulos and Winklhofer, 2001; Hair et al., 2013).

Therefore, a research partnership between academia and one large European automotive OEM has been formed, with the aim to eliminate conceptual overlaps in the initial list of indicators and to discuss potentially missing indicators.

In the indicator specification phase, literature offers multiple methods of an academic-practitioner research collaboration:

1 delphi method

2 focus groups

3 world café methodology (Kidd and Parshall, 2000; Merton, 1990; Morgan, 1997).

The delphi method uses a structured series of questionnaires with items and rankings followed by controlled feedback (Rowe and Wright, 2001). However, the iterative, several week long survey process was found to be disadvantageous as it may lead to a low response rate.

Different from the delphi method, "focus groups are a form of group interview that capitalises on communication between research participants in order to generate data" [Kitzinger, (1995), p.299]. However, it was found to be disadvantageous that the ideal focus group size is limited to 8 to 12 participants (Morrison, 1998) and that reoccurring sessions for the same group may have to be scheduled to collect rich and stable data (Kidd and Parshall, 2000).

Instead, the world café uses "intimate conversations at small café-style tables, or in small conversation clusters, [which] link, and build on each other as people move between groups, cross-pollinate ideas and make new connections around questions that really matter to their life, work, or community" [Tan and Brown, (2005), p.85]. Although the world café shares some characteristics with focus groups, it has some distinguishing features that made it more suitable for the setting of this study. First, the number of 'café' tables could be adjusted to allow involvement of 24 purchasing category managers representing a wide range of sourcing categories. Second, the world café can be held in one session avoiding problems from reoccurring sessions, such as the unavailability of participants (Brown and Isaacs, 2005).

Consequently, the study adopted the world café structure as suggested by Brown and Isaacs (2005), Prewitt (2011) and Hoffmann et al. (2013) (see Figure 3): 
1 In the early preparation, academics and practitioners engaged over several months to come to a shared foundation of the sourcing lever concept. Simultaneously, moderators, location and possible participants have been identified. Three tables with six to seven seats were set up to include multiple participants from diverse backgrounds, but still keeping an 'intimate' atmosphere that facilitates interaction (Brown and Isaacs, 2005; Prewitt, 2011).

2 Three to four sourcing levers were discussed at each table. Three discussion rounds were held, each round lasting 30 to 40 minutes. After each round, participants at each table split up to form new group constellations at different tables. Each participant had to sit at each table, but not in a pre-defined order, and had the chance to engage into discussion of all presented sourcing levers and their indicators. To stimulate table discussions, the initial list of indicators was printed on DIN A0 posters. During the discussion rounds, participants were allowed to change, add or integrate indicators by making notes on the posters.

3 At the end of the discussion rounds, academic facilitators and participants came together for a collective concluding session. Having just discussed all of the presented indicators, participants now had the chance to contrast all of them, eliminating further conceptual overlaps and inconsistent findings. Then, each participant had the chance to evaluate the results by placing stickers on the indicators they considered to be most important.

Figure 3 Indicator specification - world café steps to develop indicators

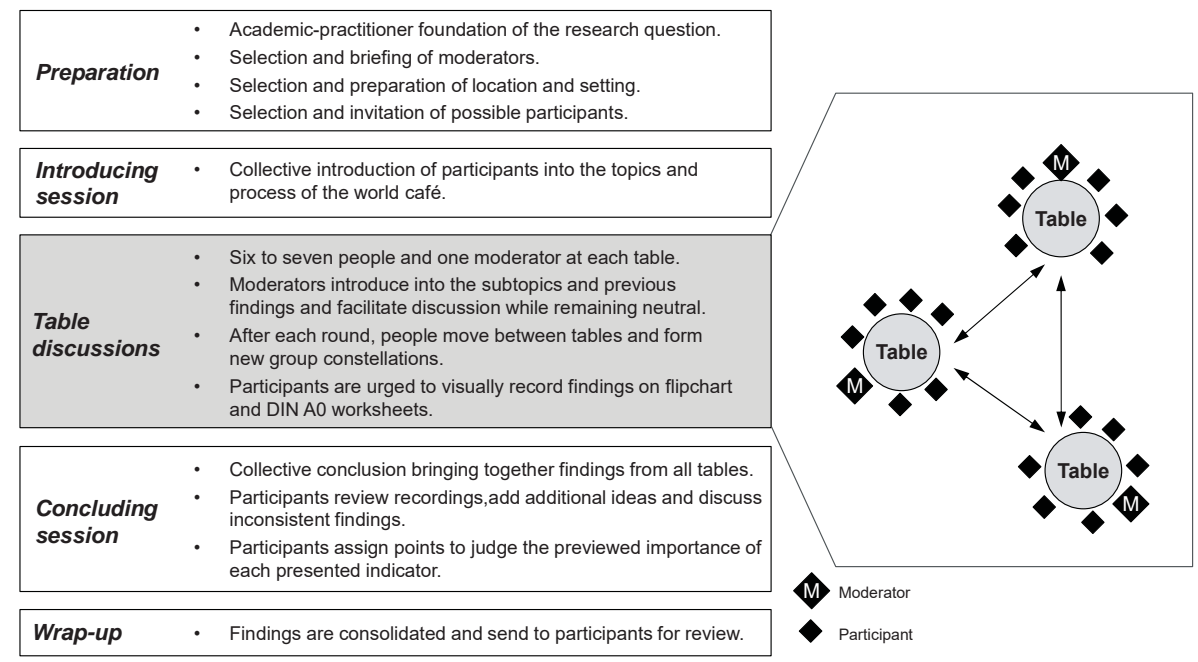

In conclusion, the initial list of indicators, identified during the literature review, could be aggregated into 23 refined indicators assigned to the seven sourcing levers (see Table 2). Throughout the discussion rounds, conceptual overlaps between the indicators have been minimised. This resulted into a comprehensive list of activities used to realise cost savings in a sourcing project. 
Table 2 Empirical evaluations - quality of formative measurement models

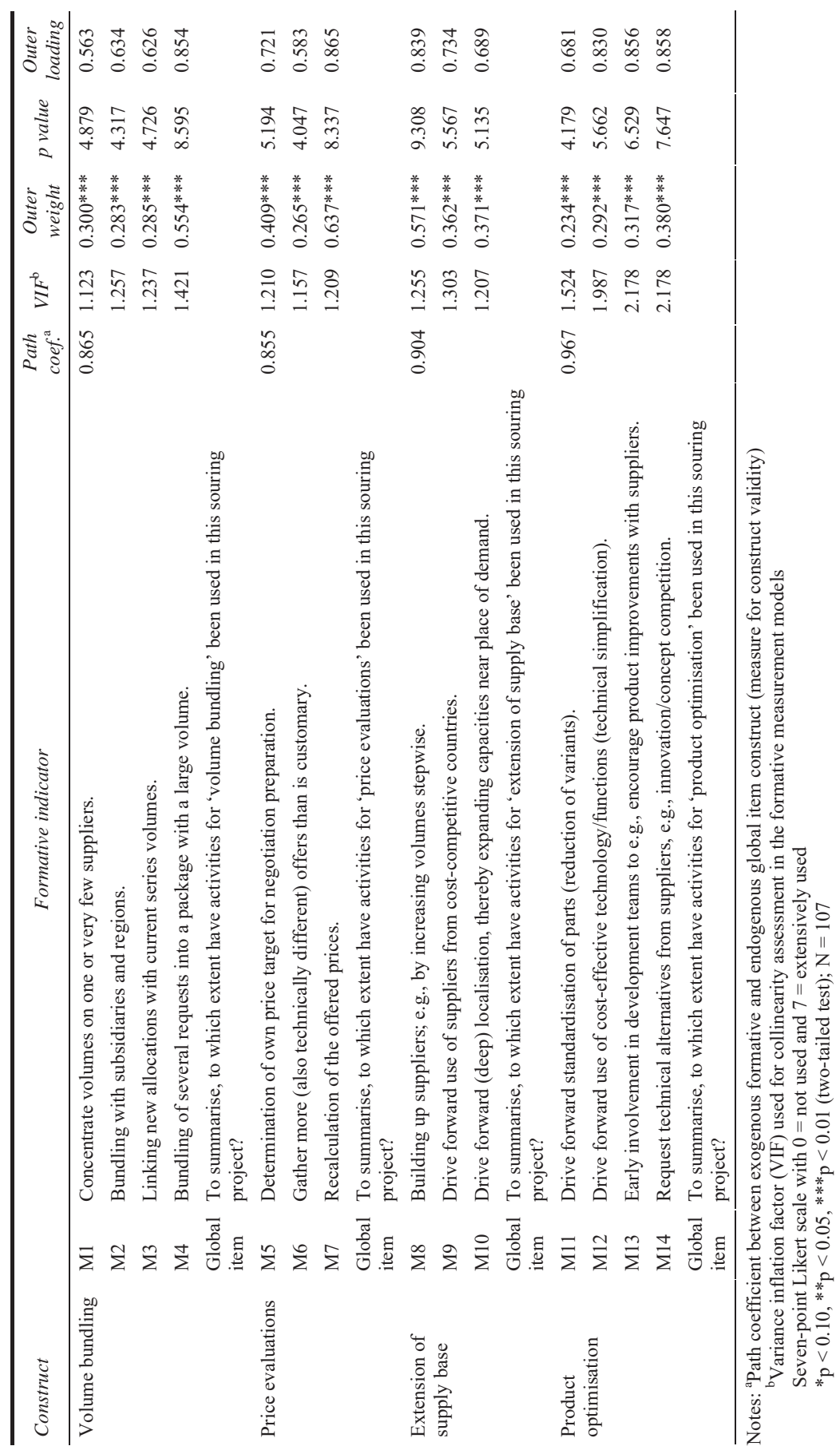


Table 2 Empirical evaluations - quality of formative measurement models (continued)

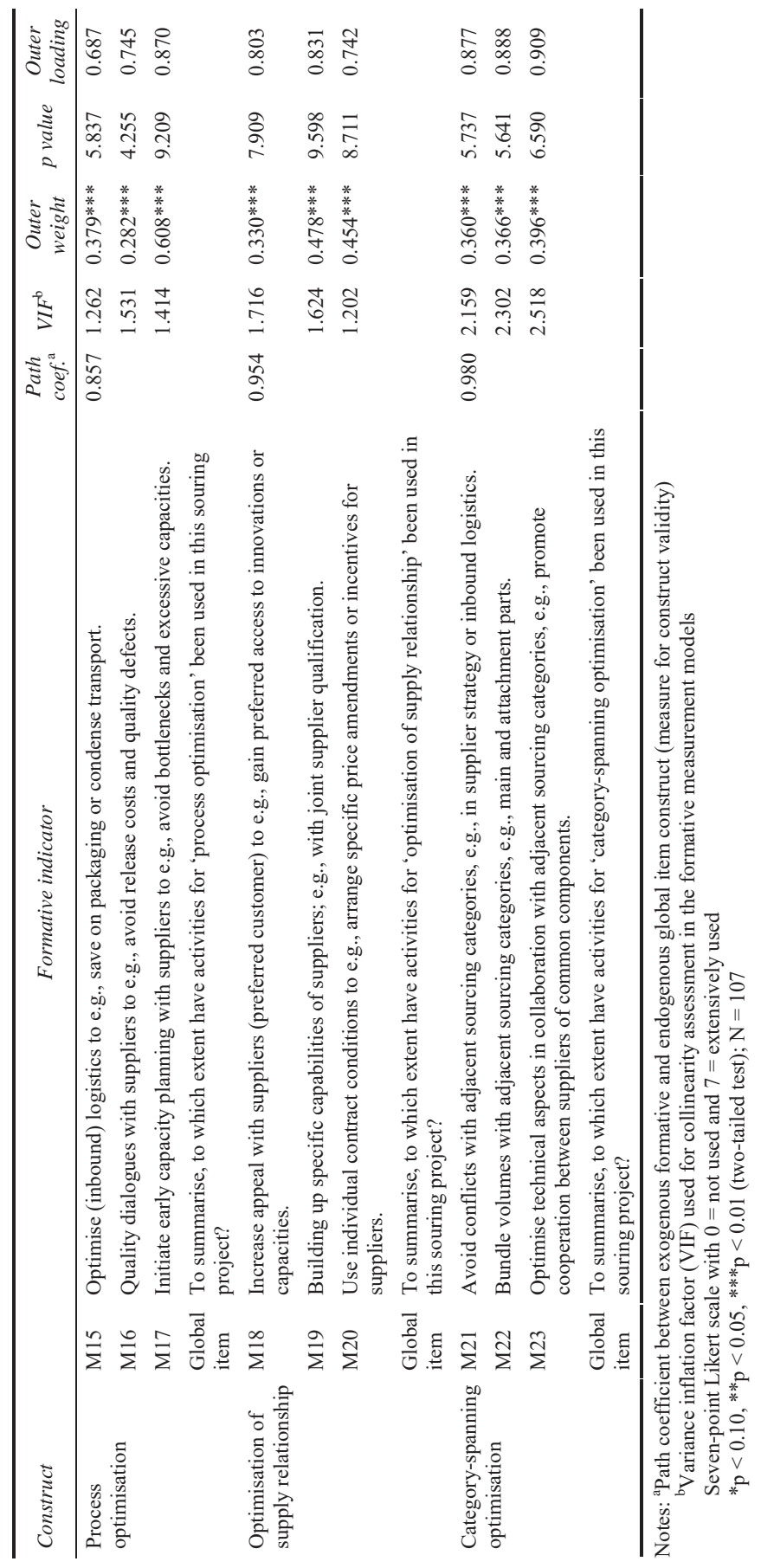


In the next section, the refined indicators were used as survey items for empirical evaluation of the measurement models.

\subsection{Empirical evaluation: testing for validity, multicollinearity and relevance}

In the third step of index development, the indicators for the sourcing lever constructs were embedded in a survey to test for validity and reliability of the measurement models.

Each indicator and the corresponding survey items were evaluated in a further pre-test by an expert panel of 27 'front-line' purchasing agents which did not previously take part in the world café process. They were asked to identify possibly vague wordings or unfamiliar terms and to check that there were no right or wrong questions.

Unit of analysis for the final survey were the multitude of sourcing projects managed by the OEM's category managers at the European headquarters. The analyses focused on direct spend only. Indirect purchases have been excluded as they involve different transaction characteristics (Cox et al., 2005; Karjalainen and Salmi, 2013). To minimise bias from recalling information, the point of supplier nomination has been chosen to question the category managers; i.e., the 'front-line' purchasing agents responsible for most strategic and operational aspects of a sourcing category. For supplier nomination, the responsible category manager has to present the strategic rationale of the respective sourcing project to the management at the corporate sourcing committee. Each time a supply contract was awarded and registered in the IT-system, the responsible category manager was visited by a researcher and the questionnaire was filled in jointly. In this way, maximum validity was ensured (Srinivasan and Ratchford, 1991). Respondents indicated the extent to which they applied each of the formative indicators (grouped into seven sourcing lever constructs), using a seven-point Likert scale $(1=$ not used to 7 = extensively used): 'For this sourcing project, which activities of the following sourcing levers are used (also in team with other functions)?' (see Table 2). A total of 107 responses has been collected.

The formative measurement models have then been tested for

1 convergent validity, using redundancy analysis with an additional global item per measurement model

2 multicollinerity, based on variance inflation factors

3 indicator relevance, provided by outer weights and loadings (Cenfetelli and Bassellier, 2009; Diamantopoulos and Winklhofer, 2001; Hair et al., 2010).

For formative measurement models, convergent validity is used to test whether all relevant facets of the construct have been sufficiently covered by the selected formative indicators (Diamantopoulos et al., 2008; Hair et al., 2013). "Convergent validity is the extent to which a measure correlates positively with other measures (indicators) of the same construct" [Hair et al., (2013), p.121]. Therefore, literature suggests a redundancy analysis, using the formatively measured construct as an exogenous variable to predict and endogenous single-item construct (Hair et al., 2013; Sarstedt et al., 2013). Global items (single-items) were added, by which respondents indicated the essence of each sourcing lever construct on a seven-point Likert scale $(1=$ not used to 7 = extensively used): 'To summarise, to which extent have measures for [sourcing lever] been used in this souring project?'. For redundancy analysis, the path coefficients have been calculated between each formative construct (exogenous) and the corresponding 
global-item construct (endogenous), using the SmartPLS 2.0 software with the path weighting scheme (Ringle et al., 2005). Results show that all path coefficients are well above the threshold of 0.8 , indicating that the used formative indicators sufficiently cover the content of the construct they purport to measure (Chin, 1998; Hair et al., 2013) (see Table 2).

As the formative measurement model is based on multiple regression, multicollinearity among the indicators can lead to instable indicator weights in a way that each indicator's influence on the construct cannot be determined distinctly (Cenfetelli and Bassellier, 2009; Diamantopoulos and Winklhofer, 2001). Therefore, literature suggests collinearity checks, based on the variance inflation factor (VIF). VIF values have been calculated for each formative construct and the corresponding indicators, using SPSS 22.0 software (IBM, 2013). Results show that all VIFs are well below the threshold of 3.3, showing that indicators are well distinct and do not carry critical levels of redundant information (Diamantopoulos and Siguaw, 2006; Hair et al., 2013; Petter et al., 2007) (see Table 2).

To evaluate indicator relevance, it has been tested whether each indicator's outer weights are significantly different from zero by means of bootstrapping (Hair et al., 2013). The bootstrapping procedure in SmartPLS 2.0 has been used to draw 5,000 random subsamples (Ringle et al., 2005). The outer weights in all formative measurement models have a p-value smaller than 0.01 , indicating a high relative contribution of the formative indicators (Hair et al., 2013). Moreover, all outer loadings in the same models are well above the threshold of 0.5 , indicating also a high absolute contribution of the indicators (see Table 2).

To summarise, survey results confirm that the developed indicators and measurement models well cover the conceptual content of the sourcing lever concept. As required, the formative indicators do not carry any critical level of redundant information and highly contribute to the construct they intend to measure. Overall, results show strong empirical support for retaining all indicators in the used survey instrument (Cenfetelli and Bassellier, 2009; Diamantopoulos et al., 2008; Hair et al., 2013; Petter et al., 2007).

\section{Conclusions and implications: study results enable future empirical investigations and serve as a checklist to identify cost saving potentials}

The study presents that, with the raise of strategic purchasing, it became commonly acknowledged that not all materials and buyer-supplier relationships are to be managed the same way (Karjalainen and Salmi, 2013). Rather, firms group similar purchases into so called sourcing categories (Cousins et al., 2008; Horn et al., 2013; Monczka et al., 2008). To achieve cost savings, each sourcing category requires a tailored set of tactics (Schiele et al., 2011). These sourcing levers have an immediate practical relevance and are at the core of decision making of 'front-line' purchasing agents. To enable future research, it was found that sourcing levers require a more explicit conceptualisation and a method of measurement (Hesping and Schiele, 2015; Luzzini et al., 2012; Wacker, 1998). But, in contemporary literature it remained unclear to which extent sourcing levers can be defined as theoretical concepts and which conceptual content they capture. To fill this gap, this study built on a framework of seven sourcing levers and developed corresponding formative measurement models. 
Contemporary literature was reviewed to define the conceptual content for each of the seven core sourcing levers and to generate an initial list of indicators. Building on this list, world café discussions with 24 category managers were held to identify further indicators and to minimise conceptual overlaps among them. The research concluded by assessing the formative measurement models in a survey of 107 sourcing project at one large European automotive OEM. Tests for convergent validity, multicollinearity and indicator relevance show strong empirical support that the developed sourcing lever constructs well tap the phenomenon of interest. The refined list of 24 indicators may serve practitioners as a checklist of potential cost saving opportunities.

Findings from the literature review identified a wide range of overlapping terms used to describe purchasing strategies and tactics. In the past, literature has not been very precise about the level of analysis to which these strategies and tactics relate. The literature about 'volume bundling' produces a good example about where different levels of analysis exist in literature. Halman et al. (2003) for example relate to the firm level of analysis and describe 'volume bundling' as an organisation-wide product platform strategy to reduce product variants. Karjalainen and van Raaij (2011) again address the functional level and limit 'volume bundling' to the purchasing function and the consolidation of demand through centralisation of purchasing activities. Yet, Schiele et al. (2011) focus on the sourcing category level and state that 'volume bundling' might be limited to only one category of purchases while other categories require different tactics. These observations correspond to recent findings calling for a hierarchical approach in purchasing strategy developement. "In purchasing, it is difficult to develop a single, all-encompassing strategy. To the contrary, a hierarchy of stages emerges when general strategy is disaggregated into executable and controllable activities" [Hesping and Schiele, (2015), p.138]. The sourcing lever constructs in this study directly address this difficulty and support academics and practitioners to take a differentiated and focused approach to implementing strategy at the so far less explored category level of purchasing.

Furthermore, the study illustrates the applicability of the world café methodology in the index development process (Brown and Isaacs, 2005; Hoffmann, 2012; Lagrosen and Lagrosen, 2013; Prewitt, 2011). Different from the majority of other quantitative and qualitative research approaches, in a world café, practitioners are seen as co-researchers rather than objects of inquiry (Susman and Evered, 1978). Relevance was demonstrated as participants highly valued to be actively engaged into discussion and evaluation of findings (Schiele and Krummaker, 2011; Vermeulen, 2007). As participants move from table to table to exchange ideas, they can further build capabilities, gaining immediate return on the time invested into the process. Construct validity could be increased as participants moved between tables, challenging and refining emerging constructs from different perspectives (Maxwell, 1992). Formative measurement models require a minimal conceptual overlap between the different indicators, avoiding multicollinearity (Diamantopoulos and Winklhofer, 2001). The world café proved to be a promising methodology to refine sometimes vague and not clearly delineated indicators into distinct constructs with minimal conceptual overlaps. 
Overall, the study's sourcing lever indices serve future research as a starting point to address relevant research questions about the antecedents, conditions and consequences of sourcing lever application, which have hardly been studied so far. Each indicator of the sourcing lever constructs represents a specific activity that purchasers can implement to achieve cost savings for a category of purchases. In a formative measurement model, each indicator's contribution to the construct can be interpreted by its weight. For example, in the 107 analysed sourcing projects, 'packaging of several requests' (M1) has been used most to achieve volume bundling. Yet, 'gathering a large number of technically different offers' (M6) has been used least for price evaluations (see Table 2). This raises new academic and practical questions: Why, did purchasers rely more on a certain activity than on another? Do the firm's processes or policies overemphasise certain activities, while others are neglected? Future research might use the indicator weights to evaluate, for example, which share each activity contributed to different dimensions of sourcing performance across multiple sourcing projects. In practice, this may allow concentrating on the most promising levers depending on the performance goals to be realised.

\subsection{Implications: sourcing tactics have become measurable}

The previous conclusions lead to a multiple theoretical and managerial implications:

1 Sourcing levers are tactics that purchasing teams use to fulfil cost savings targets. Therefore, it is surprising that this paper is one of few studies that systematically addresses cost saving approaches for a sourcing category. For the first time, the study reports results from a comprehensive literature review on sourcing tactics to implement strategy at the category level of purchasing. It lists, delineates and groups a wide range of cost saving approaches as an important step towards theory building (Meredith, 1993). The presented framework of seven sourcing levers can serve to structure existing knowledge and academic discussion. Future research may use the results to contrast sourcing lever application and performance outcomes across sourcing categories. Does the 'product optimisation' lever for example lead to different performance outcomes in a sourcing category with low and high technological complexity?

2 None of the sourcing levers have systematically been conceptually delineated and empirically evaluated before. Therefore, it is not surprising, that the literature review revealed large conceptual overlaps between the identified cost saving approaches. Multiple wordings have been used to describe aspects that, conceptually, appear very similar. This complicated or even hindered academic reasoning and cross-study comparison (Speed, 1993). To overcome this barrier for academic progress, this study highly engaged academics and practitioners during the research process. Using world café methodology, conceptual overlaps between the cost saving approaches, found in literature have been minimised. Aggregation and abstraction led to 23 distinct indicators. Instead of using a confusing amount of conceptually overlapping concepts, future research may focus on this aggregated list of cost saving approaches, covering all of the main aspects of the sourcing lever concept. 
3 The study results have an immediate practical relevance as they reveal a wide range of cost saving approaches. The developed list of indicators represents specific, actionable activities that may serve practitioners as a 'toolbox' or 'checklist' to plan upcoming sourcing activities and to discuss improvement potentials that have not been addressed so far. The identified cost saving approaches may be used in cross-functional lever analysis workshops that have been described as a promising, new cost-cutting methodology (Schiele, 2007; Schiele et al., 2011; Schuh et al., 2011). Practitioners might, for example, evaluate whether they have considered all potential sourcing levers to achieve their goals or if their choice of tactics fits to the approaches taken in another sourcing category.

4 So far, research had no measures to capture the conceptual content of the sourcing lever concept. With this study, indices with formative indicators have become available and can be applied to a wide range of practical and academic questions. In contemporary literature, the relationships of sourcing levers to other constructs remain unclear. The antecedents, conditions and consequences of sourcing lever application have hardly been studied so far. Multiple research questions arise: Under which internal organisational and external supply market conditions are sourcing levers most successful? How do sourcing levers influence cost, innovation and other performance aspects? Which configurations of sourcing levers are most successful? Do potential trade-offs exist among sourcing levers, in a way that certain sourcing lever combinations reduce overall expected performance? Which sourcing levers can be combined to realise synergies and to maximise overall cost savings? In which order shall sourcing levers be applied to reach most cost savings? Are certain sourcing levers more successful at the beginning while others should be applied preferably at the end of a sourcing project? Do certain sourcing levers lose their effect when being applied several times in the same sourcing category? Can sourcing levers be added to regain cost saving potentials from sourcing levers that lost their potential over time? How do cross-functional sourcing teams influence the choice and success of sourcing levers? What are the required competencies of category managers to apply sourcing levers most successfully? The list of possible research questions is extensive. This paper offers the instruments to address several of them.

\subsection{Limitations: sourcing lever indices - a work-in-progress}

The development of sourcing lever indices can still be considered as a work-in-progress. A number of limitations suggest further research:

1 The research took part in one large European automotive OEM and focused on direct spend only. Findings from the automotive industry are generally expected to be more generalisable than from other industries. Still, further data collection for additional testing of the developed sourcing lever indices in other industries, including indirect, service-based spend is desirable. Broader cross-industrial investigations in further regions and cultural settings might help to strengthen the usability of the developed constructs across a wider range of research problems. 
2 The developed measurement models have been grounded in recent literature and further investigated in the context of contemporary perceptions of 'front-line' category managers. Both, literature and practitioners' opinions can vary over time and affect how sourcing levers and corresponding activities are framed and used. Especially in the automotive industry, new technologies are constantly integrated into the product portfolio; e.g., digitalisation of the car. Future research might want to monitor these changes in this young research field and seek to deepen the knowledge about which tactics and activities 'front-line' purchasing agents may use to address upcoming challenges.

3 Purchasing agents increasingly work in cross-functional teams which can affect their choice of sourcing levers. Future research might therefore aim to broaden the evaluation of sourcing levers and integrate practitioners from further supply market-related functions such as engineering or quality into the research process.

\section{References}

Agrawal, T., Sao, A., Fernandes, K.J., Tiwari, M.K. and Kim, D.Y. (2013) 'A hybrid model of component sharing and platform modularity for optimal product family design', International Journal of Production Research, Vol. 51, No. 2, pp.614-625.

Ateş, M. (2014) Purchasing and Supply Management at the Purchase Category Level: Strategy, Structure and Performance, Erasmus Research Institute of Management (ERIM), Rotterdam, The Netherlands.

Atuahene-Gima, K. (1995) 'Involving organizational buyers in new product development', Industrial Marketing Management, Vol. 24, No. 3, pp.215-226.

Autry, C.W. and Golicic, S.L. (2010) 'Evaluating buyer-supplier relationship-performance spirals: a longitudinal study', Journal of Operations Management, Vol. 28, No. 2, pp.87-100.

Bandyopadhyay, S. (2009) 'A dynamic model of cross-category competition: theory, tests and applications', Journal of Retailing, Vol. 85, No. 4, pp.468-479.

Baxter, R. (2012) 'How can business buyers attract sellers' resources?: Empirical evidence for preferred customer treatment from suppliers', Industrial Marketing Management, Vol. 41, No. 8, pp.1249-1258.

Ben-Arieh, D. and Qian, L. (2003) 'Activity-based cost management for design and development stage', International Journal of Production Economics, Vol. 83, No. 2, pp.169-183.

Bezawada, R., Balachander, S., Kannan, P. and Shankar, V. (2009) 'Cross-category effects of aisle and display placements: a spatial modeling approach and insights', Journal of Marketing, Vol. 73, No. 3, pp.99-117.

Bhutta, K.S. and Huq, F. (2002) 'Supplier selection problem: a comparison of the total cost of ownership and analytic hierarchy process approaches', Supply Chain Management: An International Journal, Vol. 7, No. 3, pp.126-135.

Blonska, A., Storey, C., Rozemeijer, F., Wetzels, M. and de Ruyter, K. (2013) 'Decomposing the effect of supplier development on relationship benefits: the role of relational capital', Industrial Marketing Management, Vol. 42, No. 8, pp.1295-1306.

Boutellier, R. and Zagler, M. (2000) Materialgruppenmanagement und Einkaufskooperationen, Hanser Verlag, München.

Brown, J. and Isaacs, D. (2005) The World Café: Shaping our Futures through Conversations that Matter, Berrett-Koehler, San Francisco.

Cachon, G.P. and Kök, A.G. (2007) 'Category management and coordination in retail assortment planning in the presence of basket shopping consumers', Management Science, Vol. 53, No. 6, pp.934-951. 
Caniato, F., Luzzini, D. and Ronchi, S. (2014) 'Purchasing performance management systems: an empirical investigation', Production Planning \& Control, Vol. 25, No. 7, pp.616-635.

Cao, M. and Zhang, Q. (2011) 'Supply chain collaboration: impact on collaborative advantage and firm performance’, Journal of Operations Management, Vol. 29, No. 3, pp.163-180.

Castaldo, S., Zerbini, F. and Grosso, M. (2009) 'Integration of third parties within existing dyads: An exploratory study of category management programs (CMPs)', Industrial Marketing Management, Vol. 38, No. 8, pp.946-959.

Cavusgil, S.T., Yaprak, A. and Yeoh, P.L. (1993) 'A decision-making framework for global sourcing’, International Business Review, Vol. 2, No. 2, pp.143-156.

Cenfetelli, R.T. and Bassellier, G. (2009) 'Interpretation of formative measurement in information systems research', Management Information Systems Quarterly, Vol. 33, No. 4, p.7.

Chin, W.W. (1998) 'The partial least squares approach to structural equation modeling', Modern Methods for Business Research, Vol. 295, No. 2, pp.295-336.

Chintagunta, P.K. and Haldar, S. (1998) 'Investigating purchase timing behavior in two related product categories', Journal of Marketing Research, Vol. 35, No. 1, pp.43-53.

Churchill, G.A.J. (1979) 'A paradigm for developing better measures of marketing constructs', Journal of Marketing Research, Vol. 16, No. 1, pp.64-73.

Coltman, T., Devinney, T.M., Midgley, D.F. and Venaik, S. (2008) 'Formative versus reflective measurement models: two applications of formative measurement', Journal of Business Research, Vol. 61, No. 12, pp.1250-1262.

Cooper, R. and Yoshikawa, T. (1994) 'Inter-organizational cost management systems: the case of the Tokyo-Yokohama-Kamakura supplier chain', International Journal of Production Economics, Vol. 37, No. 1, pp.51-62.

Cousins, P.M., Lamming, R., Lawson, B. and Squire, B. (2008) Strategic Supply Management: Principles, Theories and Practice, Prentice Hall, Harlow.

Cox, A. (2014) Sourcing Portfolio Analysis, Earlsgate Press, London.

Cox, A., Chicksand, D., Ireland, P. and Davies, T. (2005) 'Sourcing indirect spend: a survey of current internal and external strategies for non-revenue-generating goods and services', Journal of Supply Chain Management, Vol. 41, No. 2, pp.39-51.

Cuervo-Cazurra, A., Caligiuri, P., Andersson, U. and Brannen, M.Y. (2013) 'From the editors: how to write articles that are relevant to practice', Journal of International Business Studies, Vol. 44, No. 4, pp.285-289.

Daly, S.P. and Nath, P. (2005) 'Reverse auctions for relationship marketers', Industrial Marketing Management, Vol. 34, No. 2, pp.157-166.

Danese, P. and Filippini, R. (2010) 'Modularity and the impact on new product development time performance: investigating the moderating effects of supplier involvement and interfunctional integration', International Journal of Operations \& Production Management, Vol. 30, No. 11, pp.1191-1209.

Dekkers, R. (2002) 'Strategic capacity management: meeting technological demands and performance criteria', International Journal of Production Research, Vol. 40, No. 15, pp.3895-3911.

Diamantopoulos, A. and Siguaw, J.A. (2006) 'Formative versus reflective indicators in organizational measure development: a comparison and empirical illustration', British Journal of Management, Vol. 17, No. 4, pp.263-282.

Diamantopoulos, A. and Winklhofer, H.M. (2001) 'Index construction with formative indicators: an alternative to scale development', Journal of Marketing Research, Vol. 38, No. 2, pp.269-277.

Diamantopoulos, A., Riefler, P. and Roth, K.P. (2008) 'Advancing formative measurement models', Journal of Business Research, Vol. 61, No. 12, pp.1203-1218.

Drake, P.R., Lee, D.M. and Hussain, M. (2013) 'The lean and agile purchasing portfolio model', Supply Chain Management: An International Journal, Vol. 18, No. 1, pp.3-20. 
Driedonks, B.A., Gevers, J.M. and Van Weele, A.J. (2010) 'Managing sourcing team effectiveness: the need for a team perspective in purchasing organizations', Journal of Purchasing and Supply Management, Vol. 16, No. 2, pp.109-117.

Eckhaus, E., Kogan, K. and Perlman, Y. (2013) 'Enhancing strategic supply decisions by estimating suppliers' marginal costs', Journal of Supply Chain Management, Vol. 49, No. 4, pp.96-107.

Ellram, L.M. (1996) 'A structured method for applying purchasing cost management tools', Journal of Supply Chain Management, Vol. 32, No. 1, pp.11-19.

Ellram, L.M. and Siferd, S.P. (1993) 'Purchasing: the cornerstone of the total cost of ownership concept', Journal of Business Logistics, Vol. 14, No. 1, pp.163-163.

Emiliani, M.L. (2000) 'Business-to-business online auctions: key issues for purchasing process improvement', Supply Chain Management: An International Journal, Vol. 5, No. 4, pp.176-186.

Englyst, L., Jørgensen, F., Johansen, J. and Mikkelsen, O.S. (2008) 'Commodity team motivation and performance', Journal of Purchasing and Supply Management, Vol. 14, No. 1, pp.15-27.

Essig, M. (2000) 'Purchasing consortia as symbiotic relationships: developing the concept of "consortium sourcing", European Journal of Purchasing \& Supply Management, Vol. 6, No. 1, pp.13-22.

Essig, M. (2011) 'Book reviews - purchasing and supply chain management: analysis, strategy, planning and practice', in Arjan van Weele (Ed.): Cengage Learning, Journal of Purchasing and Supply Management, 5th ed., Vol. 17, pp.143-144, ISBN: 978-1-4080-1896-5, Andover, UK.

Fliess, S. and Becker, U. (2006) 'Supplier integration - controlling of co-development processes', Industrial Marketing Management, Vol. 35, No. 1, pp.28-44.

Forker, L.B. (1997) 'Factors affecting supplier quality performance', Journal of Operations Management, Vol. 15, No. 4, pp.243-269.

Foster Jr., S.T., Wallin, C. and Ogden, J. (2011) 'Towards a better understanding of supply chain quality management practices', International Journal of Production Research, Vol. 49, No. 8, pp.2285-2300.

Gelderman, C.J. and Semeijn, J. (2006) 'Managing the global supply base through purchasing portfolio management', Journal of Purchasing and Supply Management, Vol. 12, No. 4, pp.209-217.

Ghijsen, P.W.T., Semeijn, J. and Ernstson, S. (2010) 'Supplier satisfaction and commitment: the role of influence strategies and supplier development', Journal of Purchasing and Supply Management, Vol. 16, No. 1, pp.17-26.

Gnyawali, D.R. and Madhavan, R. (2001) 'Cooperative networks and competitive dynamics: a structural embeddedness perspective', Academy of Management Review, Vol. 26, No. 3, pp.431-445.

Hair Jr., J.F., Hult, G.T.M., Ringle, C. and Sarstedt, M. (2013) A Primer on Partial Least Squares Structural Equation Modeling (PLS-SEM), SAGE Publications, Inc., London.

Hair, J.F., Black, W.C., Babin, B.J., Anderson, R.E. and Tatham, R.L. (2010) Multivariate Data Analysis, Prentice Hall, New Jersey.

Halman, J.I., Hofer, A.P. and Van Vuuren, W. (2003) 'Platform - driven development of product families: linking theory with practice', Journal of Product Innovation Management, Vol. 20, No. 2, pp.149-162.

Handfield, R.B., Krause, D.R., Scannell, T.V. and Monczka, R.M. (2000) 'Avoid pitfalls in supplier development', Sloan Management Review, Vol. 42, No. 2, pp.37-49.

Handfield, R.B., Ragatz, G.L., Peterson, K. and Monczka, R.M. (1999) 'Involving suppliers in new product development?', California Management Review, Vol. 42, No. 1, pp.59-82.

Hartley, J.L. (2000) 'Collaborative value analysis: experiences from the automotive industry', Journal of Supply Chain Management, Vol. 36, No. 3, pp.27-32. 
Hesping, F.H. and Schiele, H. (2015) 'Purchasing strategy development: a multi-level review', Journal of Purchasing and Supply Management, Vol. 21, No. 2, pp.138-150.

Hess, G. (2010) Supply-Strategien in Einkauf und Beschaffung: Systematischer Ansatz und Praxisfälle, 2nd ed., Gabler Verlag, Wiesbaden.

Hillman, A.J. and Hitt, M.A. (1999) 'Corporate political strategy formulation: a model of approach, participation, and strategy decisions', Academy of Management Review, Vol. 24, No. 4, pp.825-842.

Hines, P. and Rich, N. (1997) 'The seven value stream mapping tools', International Journal of Operations \& Production Management, Vol. 17, No. 1, pp.46-64.

Hoffmann, P. (2012) 'Innovative supply risk management', in Bogaschewsky, R., Essig, M., Lasch, R. and Stoelzle, W. (Eds.): Supply Management Research, pp.79-104, Springer, Wiesbaden.

Hoffmann, P., Schiele, H. and Krabbendam, K. (2013) 'Uncertainty, supply risk management and their impact on performance', Journal of Purchasing and Supply Management, Vol. 19, No. 3, pp.199-211.

Holweg, M., Reichhart, A. and Hong, E. (2011) 'On risk and cost in global sourcing', International Journal of Production Economics, Vol. 131, No. 1, pp.333-341.

Hong, Y. and Hartley, J.L. (2011) 'Managing the supplier-supplier interface in product development: the moderating role of technological newness', Journal of Supply Chain Management, Vol. 47, No. 3, pp.43-62.

Horn, P., Schiele, H. and Werner, W. (2013) 'The 'ugly twins': failed low-wage-country sourcing projects and their expensive replacements', Journal of Purchasing and Supply Management, Vol. 19, No. 1, pp.27-38.

Hüttinger, L., Schiele, H. and Veldman, J. (2012) 'The drivers of customer attractiveness, supplier satisfaction and preferred customer status: a literature review', Industrial Marketing Management, Vol. 41, No. 8, pp.1194-1205.

IBM (2013) IBM SPSS Statistics for Windows, Version 22.0.

Jap, S.D. (1999) 'Pie-expansion efforts: collaboration processes in buyer-supplier relationships', Journal of Marketing Research, Vol. 36, No. 4, pp.461-475.

Jarvis, C.B., MacKenzie, S.B. and Podsakoff, P.M. (2003) 'A critical review of construct indicators and measurement model misspecification in marketing and consumer research', Journal of Consumer Research, Vol. 30, No. 2, pp.199-218.

Jayaram, J. (2008) 'Supplier involvement in new product development projects: dimensionality and contingency effects', International Journal of Production Research, Vol. 46, No. 13, pp.3717-3735.

Jia, F., Lamming, R., Sartor, M., Orzes, G. and Nassimbeni, G. (2014a) 'Global purchasing strategy and international purchasing offices: evidence from case studies', International Journal of Production Economics, Vol. 154, pp.284-298.

Jia, F., Lamming, R., Sartor, M., Orzes, G. and Nassimbeni, G. (2014b) 'International purchasing offices in China: a dynamic evolution model', International Business Review, Vol. 23, No. 3, pp.580-593.

Kaicker, A., Bearden, W.O. and Manning, K.C. (1995) 'Component versus bundle pricing: the role of selling price deviations from price expectations', Journal of Business Research, Vol. 33, No. 3, pp.231-239.

Kamakura, W.A. and Kang, W. (2007) 'Chain-wide and store-level analysis for cross-category management', Journal of Retailing, Vol. 83, No. 2, pp.159-170.

Karjalainen, K. (2011) 'Estimating the cost effects of purchasing centralization - empirical evidence from framework agreements in the public sector', Journal of Purchasing and Supply Management, Vol. 17, No. 2, pp.87-97.

Karjalainen, K. and Salmi, A. (2013) 'Continental differences in purchasing strategies and tools', International Business Review, Vol. 22, No. 1, pp.112-125. 
Karjalainen, K. and van Raaij, E. (2011) 'An empirical test of contributing factors to different forms of maverick buying', Journal of Purchasing and Supply Management, Vol. 17, No. 3, pp.185-197.

Khan, O., Christopher, M. and Burnes, B. (2008) 'The impact of product design on supply chain risk: a case study', International Journal of Physical Distribution \& Logistics Management, Vol. 38, No. 5, pp.412-432.

Kidd, P.S. and Parshall, M.B. (2000) 'Getting the focus and the group: enhancing analytical rigor in focus group research', Qualitative Health Research, Vol. 10, No. 3, pp.293-308.

Kitzinger, J. (1995) 'Qualitative research. Introducing focus groups', British Medical Journal, Vol. 311, No. 7000, p.299.

Kotabe, M. and Murray, J.Y. (2004) 'Global sourcing strategy and sustainable competitive advantage', Industrial Marketing Management, Vol. 33, No. 1, pp.7-14.

Krause, D.R. and Ellram, L.M. (1997) 'Success factors in supplier development', International Journal of Physical Distribution \& Logistics Management, Vol. 27, No. 1, pp.39-52.

Krause, D.R. and Scannell, T.V. (2002) 'Supplier development practices: product- and service-based industry comparisons', Journal of Supply Chain Management, Vol. 38, No. 1, pp.13-21.

Krause, D.R., Handfield, R.B. and Scannell, T.V. (1998) 'An empirical investigation of supplier development: reactive and strategic processes', Journal of Operations Management, Vol. 17, No. 1, pp.39-58.

Krause, D.R., Handfield, R.B. and Tyler, B.B. (2007) 'The relationships between supplier development, commitment, social capital accumulation and performance improvement', Journal of Operations Management, Vol. 25, No. 2, pp.528-545.

Kroes, J.R. and Ghosh, S. (2010) 'Outsourcing congruence with competitive priorities: impact on supply chain and firm performance', Journal of Operations Management, Vol. 28, No. 2, pp.124-143.

Kulmala, H.I. (2004) 'Developing cost management in customer-supplier relationships: three case studies', Journal of Purchasing and Supply Management, Vol. 10, No. 2, pp.65-77.

Labro, E. (2006) 'Is a focus on collaborative product development warranted from a cost commitment perspective?', Supply Chain Management: An International Journal, Vol. 11, No. 6, pp.503-509.

Lagrosen, Y. and Lagrosen, S. (2013) 'The quality café as a method for organisational learning and quality development', International Conference on Management, Leadership and Governance, Bangkok, pp.203-209.

Lakemond, N., Echtelt, F. and Wynstra, F. (2001) 'A configuration typology for involving purchasing specialists in product development', Journal of Supply Chain Management, Vol. 37, No. 3, pp.11-20.

Leeflang, P.S. and Parreño-Selva, J. (2012) 'Cross-category demand effects of price promotions', Journal of the Academy of Marketing Science, Vol. 40, No. 4, pp.572-586.

Li, C. (2013) 'Sourcing for supplier effort and competition: design of the supply base and pricing mechanism', Management Science, Vol. 59, No. 6, pp.1389-1406.

Li, W., Humphreys, P.K., Yeung, A.C. and Cheng, T. (2012a) 'The impact of supplier development on buyer competitive advantage: a path analytic model', International Journal of Production Economics, Vol. 135, No. 1, pp.353-366.

Li, Y., Wei, Z., Zhao, J., Zhang, C. and Liu, Y. (2012b) 'Ambidextrous organizational learning, environmental munificence and new product performance: moderating effect of managerial ties in China', International Journal of Production Economics, Vol. 146, No. 1, pp.95-105.

Li, X., Olorunniwo, F., Jolayemi, J. and Fan, C. (2014) 'Re-examining the structure of supplier stratification matrix: a focus on differential value and relationship', International Journal of Procurement Management, Vol. 7, No. 2, pp.219-237. 
Lindblom, A., Olkkonen, R., Ollila, P. and Hyvönen, S. (2009) 'Suppliers' roles in category management: a study of supplier-retailer relationships in Finland and Sweden', Industrial Marketing Management, Vol. 38, No. 8, pp.1006-1013.

Liu, Z., Wong, Y.S. and Lee, K.S. (2010) 'Modularity analysis and commonality design: a framework for the top-down platform and product family design', International Journal of Production Research, Vol. 48, No. 12, pp.3657-3680.

Loppacher, J.S., Cagliano, R. and Spina, G. (2011) 'Key drivers of buyer-supplier relationships in global sourcing strategies', International Journal of Procurement Management, Vol. 4, No. 2, pp.156-180.

Lui, S.S. and Ngo, H.y. (2012) 'Drivers and outcomes of long-term orientation in cooperative relationships', British Journal of Management, Vol. 23, No. 1, pp.80-95.

Luo, X., Kwong, C., Tang, J., Deng, S. and Gong, J. (2011) 'Integrating supplier selection in optimal product family design', International Journal of Production Research, Vol. 49, No. 14, pp.4195-4222.

Luzzini, D., Caniato, F., Ronchi, S. and Spina, G. (2012) 'A transaction costs approach to purchasing portfolio management', International Journal of Operations \& Production Management, Vol. 32, No. 9, pp.1015-1042.

MacKenzie, S.B., Podsakoff, P.M. and Podsakoff, N.P. (2011) 'Construct measurement and validation procedures in MIS and behavioral research: integrating new and existing techniques', MIS Quarterly, Vol. 35, No. 2, pp.293-334.

Maffin, D. and Braiden, P. (2001) 'Manufacturing and supplier roles in product development', International Journal of Production Economics, Vol. 69, No. 2, pp.205-213.

Manrodt, K.B. and Vitasek, K. (2004) 'Global process standardization: a case study', Journal of Business Logistics, Vol. 25, No. 1, pp.1-23.

Maxwell, J.A. (1992) 'Understanding and validity in qualitative research', Harvard Educational Review, Vol. 62, No. 3, pp.279-301.

McGinnis, M.A. and Vallopra, R.M. (1999) 'Purchasing and supplier involvement in process improvement: a source of competitive advantage', Journal of Supply Chain Management, Vol. 35, No. 4, pp.42-50.

Melander, L and Lakemond, N. (2014) 'Variation of purchasing's involvement: case studies of supplier collaborations in new product development', International Journal of Procurement Management, Vol. 7, No. 1, pp.103-118.

Meredith, J. (1993) 'Theory building through conceptual methods', International Journal of Operations \& Production Management, Vol. 13, No. 5, pp.3-11.

Merton, R.K. (1990) Focused Interview, 2nd ed., The Free Press, New York.

Min, H., LaTour, M.S. and Williams, A. (1994) 'Positioning against foreign supply sources in an international purchasing environment', Industrial Marketing Management, Vol. 23, No. 5, pp.371-382.

Mintzberg, H. (1994) Rise and Fall of Strategic Planning, The Free Press, New York.

Modi, S.B. and Mabert, V.A. (2007) 'Supplier development: improving supplier performance through knowledge transfer', Journal of Operations Management, Vol. 25, No. 1, pp.42-64.

Mol, M.J., Van Tulder, R.J. and Beije, P.R. (2005) 'Antecedents and performance consequences of international outsourcing’, International Business Review, Vol. 14, No. 5, pp.599-617.

Monczka, R.M. and Markham, W.J. (2007) 'Category strategies and supplier management', Supply Chain Management Review, Vol. 11, No. 6, pp.24-30.

Monczka, R.M., Handfield, R.B. and Giunipero, L. (2008) Purchasing and Supply Chain Management, Cengage Learning, Mason.

Morgan, D.L. (1997) Focus Groups as Qualitative Research, 2nd ed., Sage Publications, London. Morrison, D.E. (1998) The Search for a Method: Focus Groups and the Development of Mass Communication Research, University of Luton. 
Morssinkhof, S., Wouters, M. and Warlop, L. (2011) 'Effects of providing total cost of ownership information on attribute weights in purchasing decisions', Journal of Purchasing and Supply Management, Vol. 17, No. 2, pp.132-142.

Mukhopadhyay, T. and Kekre, S. (2002) 'Strategic and operational benefits of electronic integration in B2B procurement processes', Management Science, Vol. 48, No. 10, pp.1301-1313.

Nagati, H. and Rebolledo, C. (2013) 'Supplier development efforts: the suppliers' point of view', Industrial Marketing Management, February, Vol. 25, No. 2, pp.180-188.

Nakano, M. (2009) 'Collaborative forecasting and planning in supply chains: the impact on performance in Japanese manufacturers', International Journal of Physical Distribution \& Logistics Management, Vol. 39, No. 2, pp.84-105.

Nassimbeni, G. (2006) 'International sourcing: empirical evidence from a sample of Italian firms', International Journal of Production Economics, Vol. 103, No. 2, pp.694-706.

Nellore, R. and Söderquist, K. (2000) 'Portfolio approaches to procurement: analysing the missing link to specifications', Long Range Planning, Vol. 33, No. 2, pp.245-267.

Newman, W. and Krehbiel, T.C. (2007) 'Linear performance pricing: a collaborative tool for focused supply cost reduction', Journal of Purchasing and Supply Management, Vol. 13, No. 2, pp.152-165.

Nicolini, D., Tomkins, C., Holti, R., Oldman, A. and Smalley, M. (2000) 'Can target costing and whole life costing be applied in the construction industry? Evidence from two case studies', British Journal of Management, Vol. 11, No. 4, pp.303-324.

Nollet, J. and Beaulieu, M. (2005) 'Should an organisation join a purchasing group?', Supply Chain Management: An International Journal, Vol. 10, No. 1, pp.11-17.

Nollet, J., Rebolledo, C. and Popel, V. (2012) 'Becoming a preferred customer one step at a time', Industrial Marketing Management, Vol. 41, No. 8, pp.1186-1193.

Nyaga, G.N., Whipple, J.M. and Lynch, D.F. (2010) 'Examining supply chain relationships: do buyer and supplier perspectives on collaborative relationships differ?', Journal of Operations Management, Vol. 28, No. 2, pp.101-114.

O'Keeffe, M and Fearne, A. (2002) 'From commodity marketing to category management: insights from the Waitrose category leadership program in fresh produce', Supply Chain Management: An International Journal, Vol. 7, No. 5, pp.296-301.

O'Brien, J. (2012) Category Management in Purchasing: A Strategic Approach to Maximize Business Profitability, 2nd ed., Kogan Page, London.

Parente, R.C., Baack, D.W. and Hahn, E.D. (2011) 'The effect of supply chain integration, modular production, and cultural distance on new product development: a dynamic capabilities approach', Journal of International Management, Vol. 17, No. 4, pp.278-290.

Parker, D.B., Zsidisin, G.A. and Ragatz, G.L. (2008) 'Timing and extent of supplier integration in new product development: a contingency approach', Journal of Supply Chain Management, Vol. 44, No. 1, pp.71-83.

Patala, S., Jalkala, A. and Soukka, R. (2014) 'Methods for reducing buyer perceived risk related to the adoption of technological innovations', International Journal of Procurement Management, Vol. 7, No. 1, pp.71-84.

Petter, S., Straub, D. and Rai, A. (2007) 'Specifying formative constructs in information systems research', MIS Quarterly, Vol. 31, No. 4, pp.623-656.

Pradhan, S.K. and Routroy, S. (2014) 'Development of supply chain risk mitigation strategy: a case study', International Journal of Procurement Management, Vol. 7, No. 4, pp.359-375.

Pramatari, K. (2007) 'Collaborative supply chain practices and evolving technological approaches', Supply Chain Management: An International Journal, Vol. 12, No. 3, pp.210-220.

Prewitt, V. (2011) 'Working in the cafe: lessons in group dialogue', The Learning Organization, Vol. 18, No. 3, pp.189-202. 
Prince, M., Geunes, J. and Smith, J.C. (2013) 'Procurement allocation planning with multiple suppliers under competition', International Journal of Production Research, Vol. 51, Nos. 23-24, pp.6900-6922.

Puschmann, T. and Alt, R. (2005) 'Successful use of e-procurement in supply chains', Supply Chain Management: An International Journal, Vol. 10, No. 2, pp.122-133.

Quintens, L., Pauwels, P. and Matthyssens, P. (2006) 'Global purchasing: state of the art and research directions', Journal of Purchasing and Supply Management, Vol. 12, No. 4, pp.170-181.

Ragatz, G.L., Handfield, R.B. and Petersen, K.J. (2002) 'Benefits associated with supplier integration into new product development under conditions of technology uncertainty', Journal of Business Research, Vol. 55, No. 5, pp.389-400.

Ramanathan, U. and Gunasekaran, A. (2014) 'Supply chain collaboration: impact of success in long-term partnerships', International Journal of Production Economics, January, Vol. 147, Part B, pp.252-259.

Ratha, P.C. (2014) 'Towards concurrent product and supply chain designing: a review of concepts and practices', International Journal of Procurement Management, Vol. 7, No. 4, pp.391-406.

Rese, M. (2006) 'Successful and sustainable business partnerships: how to select the right partners', Industrial Marketing Management, Vol. 35, No. 1, pp.72-82.

Ringle, C., Wende, S. and Will, A. (2005) 'SmartPLS 2', SmartPLS [online] http://www.smartpls.com.

Rogers, K.W., Purdy, L., Safayeni, F. and Duimering, P.R. (2007) 'A supplier development program: rational process or institutional image construction?', Journal of Operations Management, Vol. 25, No. 2, pp.556-572.

Romano, P. and Formentini, M. (2012) 'Designing and implementing open book accounting in buyer-supplier dyads: a framework for supplier selection and motivation', International Journal of Production Economics, Vol. 137, No. 1, pp.68-83.

Rowe, G. and Wright, G. (2001) 'Expert opinions in forecasting: the role of the Delphi technique', in Armstrong, J. (Ed.): Principles of Forecasting, pp.125-144, Kluwer Academic, Boston.

Salvador, F. and Villena, V.H. (2013) 'Supplier integration and NPD outcomes: conditional moderation effects of modular design competence', Journal of Supply Chain Management, Vol. 49, No. 1, pp.87-113.

Sarstedt, M., Wilczynski, P. and Melewar, T. (2013) 'Measuring reputation in global markets - a comparison of reputation measures' convergent and criterion validities', Journal of World Business, Vol. 48, No. 3, pp.329-339.

Sartor, M., Orzes, G., Nassimbeni, G., Jia, F. and Lamming, R. (2014) 'International purchasing offices: literature review and research directions', Journal of Purchasing and Supply Management, Vol. 20, No. 1, pp.1-17.

Schiele, H. (2007) 'Supply-management maturity, cost savings and purchasing absorptive capacity: testing the procurement-performance link', Journal of Purchasing and Supply Management, Vol. 13, No. 4, pp.274-293.

Schiele, H. and Krummaker, S. (2011) 'Consortium benchmarking: collaborative a cademic-practitioner case study research', Journal of Business Research, Vol. 64, No. 10, pp.1137-1145.

Schiele, H., Calvi, R. and Gibbert, M. (2012) 'Customer attractiveness, supplier satisfaction and preferred customer status: introduction, definitions and an overarching framework', Industrial Marketing Management, Vol. 41, No. 8, pp.1178-1185.

Schiele, H., Horn, P. and Vos, B. (2011) 'Estimating cost-saving potential from international sourcing and other sourcing levers: relative importance and trade-offs', International Journal of Physical Distribution \& Logistics Management, Vol. 41, No. 3, pp.315-336.

Schoenherr, T. and Mabert, V.A. (2008) 'The use of bundling in B2B online reverse auctions', Journal of Operations Management, Vol. 26, No. 1, pp.81-95. 
Schotanus, F. and Telgen, J. (2007) 'Developing a typology of organisational forms of cooperative purchasing', Journal of Purchasing and Supply Management, Vol. 13, No. 1, pp.53-68.

Schotanus, F., Telgen, J. and Boer, L. (2010) 'Critical success factors for managing purchasing groups', Journal of Purchasing and Supply Management, Vol. 16, No. 1, pp.51-60.

Schuh, C. and Bremicker, M. (2005) Der Einkauf als Margenmotor: Methoden zur Kostensenkung: mit Fallbeispielen, Gabler Verlag, Wiesbaden.

Schuh, C., Raudabaugh, J.L., Kromoser, R., Strohmer, M.F. and Triplat, A. (2011) The Purchasing Chessboard: 64 Methods to Reduce Costs and Increase Value with Suppliers, Springer, New York.

Schulze, M., Seuring, S. and Ewering, C. (2012) 'Applying activity-based costing in a supply chain environment', International Journal of Production Economics, Vol. 135, No. 2, pp.716-725.

Schumacher, S.C., Schiele, H., Contzen, M. and Zachau, T. (2008) Die 3 Faktoren des Einkaufs: Einkauf und Lieferanten strategisch positionieren, Wiley-VCH Verlag, Weinheim.

Sillanpää, I., Shahzad, K. and Sillanpää, E. (2015) 'Supplier development and buyer-supplier relationship strategies - a literature review', International Journal of Procurement Management, Vol. 8, No. 1, pp.227-250.

Smals, R.G. and Smits, A.A. (2012) 'Value for value - the dynamics of supplier value in collaborative new product development', Industrial Marketing Management, Vol. 41, No. 1, pp.156-165.

Smart, A. and Dudas, A. (2007) 'Developing a decision-making framework for implementing purchasing synergy: a case study’, International Journal of Physical Distribution \& Logistics Management, Vol. 37, No. 1, pp.64-89.

Smart, A. and Harrison, A. (2003) 'Online reverse auctions and their role in buyer-supplier relationships', Journal of Purchasing and Supply Management, Vol. 9, No. 5, pp.257-268.

Smeltzer, L.R. and Carr, A.S. (2003) 'Electronic reverse auctions: promises, risks and conditions for success', Industrial Marketing Management, Vol. 32, No. 6, pp.481-488.

Smith, J.M. (1999) 'Item selection for global purchasing', European Journal of Purchasing \& Supply Management, Vol. 5, Nos. 3-4, pp.117-127.

Song, I. and Chintagunta, P.K. (2006) 'Measuring cross-category price effects with aggregate store data', Management Science, Vol. 52, No. 10, pp.1594-1609.

Song, M. and Di Benedetto, C.A. (2008) 'Supplier's involvement and success of radical new product development in new ventures', Journal of Operations Management, Vol. 26, No. 1, pp.1-22.

Speed, R. (1993) 'Maximizing the potential of strategic typologies for marketing strategy research', Journal of Strategic Marketing, Vol. 1, No. 3, pp.171-188.

Srinivasan, N. and Ratchford, B.T. (1991) 'An empirical test of a model of external search for automobiles', Journal of Consumer Research, Vol. 18, No. 2, pp.233-242.

Stollenwerk, A. (2012) Wertschöpfungsmanagement im Einkauf: Analysen-Strategien-Methoden- Kennzahlen, Gabler Verlag, Wiesbaden.

Stremersch, S. and Tellis, G.J. (2002) 'Strategic bundling of products and prices: a new synthesis for marketing', Journal of Marketing, Vol. 66, No. 1, pp.55-72.

Stump, R.L. (1995) 'Antecedents of purchasing concentration: a transaction cost explanation', Journal of Business Research, Vol. 34, No. 2, pp.145-157.

Sucky, E. and Durst, S.M. (2013) 'Supplier development: current status of empirical research', International Journal of Procurement Management, Vol. 6, No. 1, pp.92-127.

Sundtoft, H.K. and Sigurbjornsson, T. (2013) 'How do category managers manage? - A network perspective', IPSERA Conference, Nantes.

Susman, G.I. and Evered, R.D. (1978) 'An assessment of the scientific merits of action research', Administrative Science Quarterly, pp.582-603. 
Tai, Y-M., Ho, C-F. and Wu, W-H. (2010) 'The performance impact of implementing web-based e-procurement systems', International Journal of Production Research, Vol. 48, No. 18, pp.5397-5414.

Tan, S. and Brown, J. (2005) 'The world café in singapore creating a learning culture through dialogue', The Journal of Applied Behavioral Science, Vol. 41, No. 1, pp.83-90.

Tella, E. and Virolainen, V-M. (2005) 'Motives behind purchasing consortia', International Journal of Production Economics, 8 January, Vols. 93-94, pp.161-168.

Thomas, E. (2013) 'Supplier integration in new product development: computer mediated communication, knowledge exchange and buyer performance', Industrial Marketing Management, Vol. 42, No. 6, pp.890-899.

Thomas, L., Autio, E. and Gann, D. (2014) 'Architectural leverage: putting platforms in context', The Academy of Management Perspectives, Vol. 28, No. 2, pp.198-219.

Tornberg, K., Jämsen, M. and Paranko, J. (2002) 'Activity-based costing and process modeling for cost-conscious product design: a case study in a manufacturing company', International Journal of Production Economics, Vol. 79, No. 1, pp.75-82.

Tuten, T.L. and Urban, D.J. (2001) 'An expanded model of business-to-business partnership formation and success', Industrial Marketing Management, Vol. 30, No. 2, pp.149-164.

Van Weele, A.J. (2010) Purchasing and Supply Chain Management: Analysis, Strategy, Planning and Practice, 5th ed., Cengage Learning EMEA, Hampshire.

Vermeulen, F. (2007) "I shall not remain insignificant': adding a second loop to matter more', Academy of Management Journal, Vol. 50, No. 4, pp.754-761.

Wacker, J.G. (1998) 'A definition of theory: research guidelines for different theory-building research methods in operations management', Journal of Operations Management, Vol. 16, No. 4, pp.361-385.

Wagner, S.M. (2011) 'Supplier development and the relationship life-cycle', International Journal of Production Economics, Vol. 129, No. 2, pp.277-283.

Wagner, S.M. (2012) 'Tapping supplier innovation', Journal of Supply Chain Management, Vol. 48, No. 2, pp.37-52.

Wagner, S.M. and Bode, C. (2006) 'An empirical investigation into supply chain vulnerability', Journal of Purchasing and Supply Management, Vol. 12, No. 6, pp.301-312.

Wagner, S.M. and Johnson, J.L. (2004) 'Configuring and managing strategic supplier portfolios', Industrial Marketing Management, Vol. 33, No. 8, pp.717-730.

Wang, S. and Archer, N. (2007) 'Business-to-business collaboration through electronic marketplaces: an exploratory study', Journal of Purchasing and Supply Management, Vol. 13, No. 2, pp.113-126.

Weber, M., Hiete, M., Lauer, L. and Rentz, O. (2010) 'Low cost country sourcing and its effects on the total cost of ownership structure for a medical devices manufacturer', Journal of Purchasing and Supply Management, Vol. 16, No. 1, pp.4-16.

Wee, H-M., Lee, M-C., Yu, J.C. and Wang, C. (2011) 'Optimal replenishment policy for a deteriorating green product: life cycle costing analysis', International Journal of Production Economics, Vol. 133, No. 2, pp.603-611.

Whitney, D., Luo, J. and Heller, D.A. (2014) 'The Benefits and Constraints of Temporary Sourcing Diversification in Supply Chain Disruption and Recovery', Journal of Purchasing and Supply Management, Vol. 20, No. 4, pp.238-250.

Williams, A.J. and Smith, W.C. (1990) 'Involving purchasing in product development', Industrial Marketing Management, Vol. 19, No. 4, pp.315-319.

Wynstra, F., Weggeman, M. and Van Weele, A. (2003) 'Exploring purchasing integration in product development', Industrial Marketing Management, Vol. 32, No. 1, pp.69-83.

Yang, Z., Aydin, G., Babich, V. and Beil, D.R. (2009) 'Supply disruptions, asymmetric information, and a backup production option', Management Science, Vol. 55, No. 2, pp.192-209. 
Yeniyurt, S., Henke Jr., J.W. and Yalcinkaya, G. (2014) 'A longitudinal analysis of supplier involvement in buyers' new product development: working relations, inter-dependence, co-innovation, and performance outcomes', Journal of the Academy of Marketing Science, Vol. 42, No. 3, pp.291-308.

Yeung, K., Lee, P.K., Yeung, A.C. and Cheng, T. (2013) 'Supplier partnership and cost performance: the moderating roles of specific investments and environmental uncertainty', International Journal of Production Economics, Vol. 144, No. 2, pp.546-559.

Ylimäki, J. (2014) 'A dynamic model of supplier-customer product development collaboration strategies', Industrial Marketing Management, Vol. 43, No. 6, pp.996-1004.

Yoshikawa, T., Innes, J. and Mitchell, F. (1994) 'Applying functional cost analysis in a manufacturing environment', International Journal of Production Economics, Vol. 36, No. 1, pp.53-64.

Zengin, Y. and Ada, E. (2010) 'Cost management through product design: target costing approach', International Journal of Production Research, Vol. 48, No. 19, pp.5593-5611.

\section{Appendix}

Table A1 Literature review - sourcing levers and corresponding activities identified in literature

\begin{tabular}{|c|c|c|}
\hline Sourcing lever & Activity & Source \\
\hline \multirow[t]{6}{*}{$\begin{array}{l}\text { Volume } \\
\text { bundling }\end{array}$} & $\begin{array}{l}\text { Bundling complementary } \\
\text { products }\end{array}$ & Kaicker et al. (1995) \\
\hline & Outsourcing/make-or-buy & Kroes and Ghosh (2010) \\
\hline & Purchasing group/consortia & $\begin{array}{l}\text { Essig (2000), Nollet and Beaulieu (2005), } \\
\text { Tella and Virolainen (2005) } \\
\text { and Wang and Archer (2007) }\end{array}$ \\
\hline & Reducing suppliers/sources & $\begin{array}{l}\text { Stump (1995) and Wagner and Bode } \\
\text { (2006) }\end{array}$ \\
\hline & Single sourcing & Wagner and Bode (2006) \\
\hline & $\begin{array}{l}\text { Standardising } \\
\text { products/reducing variants }\end{array}$ & Schoenherr and Mabert (2008) \\
\hline \multirow[t]{7}{*}{ Price evaluation } & Cost or bid breakdown & $\begin{array}{l}\text { Cooper and Yoshikawa (1994) and Ellram } \\
\text { (1996) }\end{array}$ \\
\hline & Value engineering/analysis & $\begin{array}{l}\text { Kulmala (2004), Yoshikawa et al. (1994) } \\
\text { and Zengin and Ada (2010) }\end{array}$ \\
\hline & Reverse (online) auctions & $\begin{array}{l}\text { Daly and Nath (2005), Eckhaus et al. } \\
\text { (2013), Emiliani (2000), Jap (1999), } \\
\text { Smart and Harrison (2003) and } \\
\text { Smeltzer and Carr (2003) }\end{array}$ \\
\hline & Activity-based costing & $\begin{array}{l}\text { Ben-Arieh and Qian (2003), } \\
\text { Schulze et al. (2012), Tornberg et al. } \\
\text { (2002) and Weber et al. (2010) }\end{array}$ \\
\hline & Life cycle costing analysis & Wee et al. (2011) \\
\hline & Open book accounting & Kulmala (2004) \\
\hline & Linear performance pricing & Newman and Krehbiel (2007) \\
\hline
\end{tabular}


Table A1 Literature review - sourcing levers and corresponding activities identified in literature (continued)

\begin{tabular}{|c|c|c|}
\hline Sourcing lever & Activity & Source \\
\hline \multirow[t]{4}{*}{ Price evaluation } & $\begin{array}{l}\text { Total cost of ownership } \\
\text { analysis }\end{array}$ & $\begin{array}{l}\text { Bhutta and Huq (2002), Ellram and Perrott } \\
\text { Siferd (1993), Morssinkhof et al. (2011) } \\
\text { and Weber et al. (2010) }\end{array}$ \\
\hline & Value stream mapping & Hines and Rich (1997) \\
\hline & Competitive price comparison & Ellram (1996) \\
\hline & Target pricing/costing & $\begin{array}{l}\text { Cooper and Yoshikawa (1994), } \\
\text { Kulmala (2004), Nicolini et al. (2000) and } \\
\text { Zengin and Ada (2010) }\end{array}$ \\
\hline \multirow{12}{*}{$\begin{array}{l}\text { Extension of } \\
\text { supply } \\
\text { base }\end{array}$} & Building up sources & $\begin{array}{l}\text { Handfield et al. (2000) and } \\
\text { Krause et al. (1998) }\end{array}$ \\
\hline & Global scouting & Sartor et al. (2014) \\
\hline & Global sourcing & $\begin{array}{l}\text { Cavusgil et al. (1993), Holweg et al. } \\
(2011) \text {, Kotabe and Murray (2004) and } \\
\text { Mol et al. (2005) }\end{array}$ \\
\hline & Import sourcing & Nassimbeni (2006) \\
\hline & International outsourcing & Mol et al. (2005) \\
\hline & $\begin{array}{l}\text { International purchasing } \\
\text { offices }\end{array}$ & Jia et al. (2014b) and Sartor et al. (2014) \\
\hline & International sourcing & $\begin{array}{l}\text { Min et al. (1994), Mol et al. (2005), } \\
\text { Nassimbeni (2006) and Schiele et al. } \\
(2011)\end{array}$ \\
\hline & Multiple sourcing & Whitney et al. (2014) \\
\hline & Offshore sourcing & Nassimbeni (2006) \\
\hline & Supplier diversification & Whitney et al. (2014) \\
\hline & Supply base configuration & Wagner and Johnson (2004) \\
\hline & World-wide sourcing & Nassimbeni (2006) \\
\hline \multirow[t]{7}{*}{$\begin{array}{l}\text { Product } \\
\text { optimisation }\end{array}$} & Co-development & $\begin{array}{l}\text { Fliess and Becker (2006) and } \\
\text { Wagner (2012) }\end{array}$ \\
\hline & Develop or buy decision & Wynstra et al. (2003) \\
\hline & $\begin{array}{l}\text { Integrating development } \\
\text { activities of different supplier }\end{array}$ & $\begin{array}{l}\text { Hong and Hartley (2011) and } \\
\text { Wynstra et al. (2003) }\end{array}$ \\
\hline & Modular product design & $\begin{array}{l}\text { Danese and Filippini (2010), Hong and } \\
\text { Hartley (2011), Luo et al. (2011), Parente } \\
\text { et al. (2011) and Salvador and Villena } \\
\text { (2013) }\end{array}$ \\
\hline & $\begin{array}{l}\text { Product development } \\
\text { collaboration }\end{array}$ & Ylimäki (2014) \\
\hline & Product platforms & $\begin{array}{l}\text { Salvador and Villena (2013) and } \\
\text { Thomas et al. (2014) }\end{array}$ \\
\hline & $\begin{array}{l}\text { Purchasing integration in } \\
\text { product development }\end{array}$ & $\begin{array}{l}\text { Hong and Hartley (2011), Lakemond et al. } \\
\text { (2001), Williams and Smith (1990) and } \\
\text { Wynstra et al. (2003) }\end{array}$ \\
\hline
\end{tabular}


Table A1 Literature review - sourcing levers and corresponding activities identified in literature (continued)

\begin{tabular}{|c|c|c|}
\hline Sourcing lever & Activity & Source \\
\hline \multirow[t]{2}{*}{$\begin{array}{l}\text { Product } \\
\text { optimisation }\end{array}$} & $\begin{array}{l}\text { Supplier } \\
\text { integration/involvement in } \\
\text { (collaborative) new product } \\
\text { development }\end{array}$ & $\begin{array}{l}\text { Atuahene-Gima (1995), Fliess and Becker } \\
\text { (2006), Handfield et al. (1999), Jayaram } \\
\text { (2008), Labro (2006), } \\
\text { Parker et al. (2008), Ragatz et al. (2002), } \\
\text { Salvador and Villena (2013), Smals and } \\
\text { Smits (2012), Song and Di Benedetto } \\
\text { (2008), Thomas (2013) and } \\
\text { Yeniyurt et al. (2014) }\end{array}$ \\
\hline & Value engineering & $\begin{array}{l}\text { Labro (2006), Maffin and Braiden (2001) } \\
\text { and McGinnis and Vallopra (1999) }\end{array}$ \\
\hline \multirow[t]{9}{*}{$\begin{array}{l}\text { Process } \\
\text { optimisation }\end{array}$} & Process standardisation & $\begin{array}{l}\text { Manrodt and Vitasek (2004) and Quintens } \\
\text { et al. (2006) }\end{array}$ \\
\hline & Capacity management & Dekkers (2002) \\
\hline & $\begin{array}{l}\text { Collaborative processes } \\
\text { operation }\end{array}$ & $\begin{array}{l}\text { Cao and Zhang (2011), Nakano (2009), } \\
\text { Pramatari (2007) and Ramanathan and } \\
\text { Gunasekaran (2014) }\end{array}$ \\
\hline & Electronic data interchange & $\begin{array}{l}\text { Mukhopadhyay and Kekre (2002) and } \\
\text { Pramatari (2007) }\end{array}$ \\
\hline & E-procurement & Puschmann and Alt (2005) \\
\hline & Information sharing & Cao and Zhang (2011) \\
\hline & Process integration & Cao and Zhang (2011) \\
\hline & $\begin{array}{l}\text { Supply chain quality } \\
\text { management }\end{array}$ & Forker (1997) and Foster et al. (2011) \\
\hline & $\begin{array}{l}\text { Supply chain risk } \\
\text { management }\end{array}$ & Tai et al. (2010) \\
\hline \multirow[t]{8}{*}{$\begin{array}{l}\text { Optimisation } \\
\text { of supply } \\
\text { relationship }\end{array}$} & $\begin{array}{l}\text { Becoming a preferred } \\
\text { customer }\end{array}$ & $\begin{array}{l}\text { Baxter (2012), Nagati and Rebolledo } \\
\text { (2013), Nollet et al. (2012) and } \\
\text { Schiele et al. (2012) }\end{array}$ \\
\hline & Dedicated investments & $\begin{array}{l}\text { Nyaga et al. (2010) and } \\
\text { Yeung et al. (2013) }\end{array}$ \\
\hline & Develop strong partnership & $\begin{array}{l}\text { Autry and Golicic (2010), Lui and Ngo } \\
\text { (2012), Nyaga et al. (2010), Rese (2006), } \\
\text { Rogers et al. (2007) } \\
\text { and Tuten and Urban (2001) }\end{array}$ \\
\hline & Ensure equitable treatment & Nollet et al. (2012) \\
\hline & Information sharing/exchange & $\begin{array}{l}\text { Li et al. (2012b), Modi and Mabert (2007), } \\
\text { Nollet et al. (2012), } \\
\text { Nyaga et al. (2010), Rogers et al. (2007) } \\
\text { and Tuten and Urban (2001) }\end{array}$ \\
\hline & Joint action/events & $\begin{array}{l}\text { Lui and Ngo (2012) and } \\
\text { Nollet et al. (2012) }\end{array}$ \\
\hline & Long-term commitment & Li et al. (2012a) \\
\hline & Profit/cost sharing & Rese (2006) \\
\hline
\end{tabular}


Table A1 Literature review - sourcing levers and corresponding activities identified in literature (continued)

\begin{tabular}{|c|c|c|}
\hline Sourcing lever & Activity & Source \\
\hline \multirow{5}{*}{$\begin{array}{l}\text { Optimisation } \\
\text { of supply } \\
\text { relationship }\end{array}$} & Recognition and awards & $\begin{array}{l}\text { Krause and Ellram (1997) and } \\
\text { Krause and Scannell (2002) }\end{array}$ \\
\hline & Reverse marketing & Nollet et al. (2012) \\
\hline & Strategic alliances & Lui and Ngo (2012) \\
\hline & Supplier development & $\begin{array}{l}\text { Blonska et al. (2013), Ghijsen et al. (2010), } \\
\text { Handfield et al. (2000), } \\
\text { Krause and Ellram (1997), } \\
\text { Krause et al. (1998), Krause and Scannell } \\
\text { (2002), Li et al. (2012a), Modi and Mabert } \\
\text { (2007), Nagati and Rebolledo (2013), } \\
\text { Rogers et al. (2007) and Wagner (2011) }\end{array}$ \\
\hline & Joint working teams & $\begin{array}{l}\text { Krause and Ellram (1997), Krause and } \\
\text { Scannell (2002), Nagati and Rebolledo } \\
\text { (2013) and Wagner (2011) }\end{array}$ \\
\hline \multirow{6}{*}{$\begin{array}{l}\text { Category- } \\
\text { spanning } \\
\text { optimisation }\end{array}$} & Category leadership & O’Keeffe and Fearne (2002) \\
\hline & Cooperative purchasing & $\begin{array}{l}\text { Driedonks (2010), Englyst et al. (2008) and } \\
\text { Schotanus et al. (2010) }\end{array}$ \\
\hline & Cross-category competition & Bandyopadhyay (2009) \\
\hline & Cross-category demand & $\begin{array}{l}\text { Bezawada et al. (2009), Cachon and Kök } \\
\text { (2007), Chintagunta and Haldar (1998) and } \\
\text { Leeflang and Parreño-Selva (2012) }\end{array}$ \\
\hline & $\begin{array}{l}\text { Cross-category marketing } \\
\text { activities }\end{array}$ & Song and Chintagunta (2006) \\
\hline & $\begin{array}{l}\text { Optimising technical aspects } \\
\text { across sourcing categories }\end{array}$ & $\begin{array}{l}\text { Agrawal et al. (2013) and } \\
\text { Thomas et al. (2014) }\end{array}$ \\
\hline
\end{tabular}

